\title{
DNA RADIATION ENVIRONMENTS PROGRAM SPRING 1991 2-METER BOX EXPERIMENTS AND ANALYSES
}

\author{
R. T. Santoro \\ S. Y. Whitaker \\ Clark Atlanta University \\ Atlanta, Georgia
}

Date Published: March 1993

Prepared by the

OAK RIDGE NATIONAL LABORATORY

Oak Ridge, Tennessee

managed by

MARTIN MARIETTA ENERGY SYSTEMS, INC

for the

U. S. DEPARTMENT OF ENERGY

under contract DE-AC05-84OR21400 


\section{CONTENTS}

Page

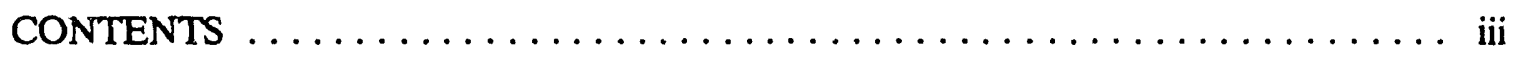

LIST OF TABLES $\ldots \ldots \ldots \ldots \ldots \ldots \ldots \ldots \ldots \ldots \ldots \ldots \ldots \ldots$

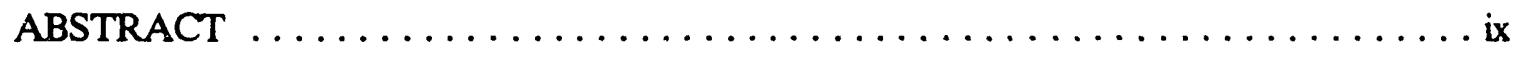

I. INTRODUCTION $\ldots \ldots \ldots \ldots \ldots \ldots \ldots \ldots \ldots \ldots \ldots \ldots \ldots \ldots \ldots \ldots \ldots \ldots$

II. DETAILS OF THE MEASUREMENTS $\ldots \ldots \ldots \ldots \ldots \ldots \ldots \ldots \ldots$

II.A. APRF MEASUREMENTS $\ldots \ldots \ldots \ldots \ldots \ldots \ldots \ldots \ldots \ldots \ldots$

II.B. AFRRI MEASUREMENTS $\ldots \ldots \ldots \ldots \ldots \ldots \ldots \ldots \ldots \ldots \ldots \ldots$

II.C. HDL MEASUREMENTS $\ldots \ldots \ldots \ldots \ldots \ldots \ldots \ldots \ldots \ldots \ldots \ldots \ldots \ldots \ldots \ldots \ldots$

II.D. ETCA MEASUREMENTS $\ldots \ldots \ldots \ldots \ldots \ldots \ldots \ldots \ldots$

II.2. COMPARISONS OF MEASURED DOSE RATES $\ldots \ldots \ldots \ldots \ldots \ldots$

II.2.A. Neutron Dose Rates $\ldots \ldots \ldots \ldots \ldots \ldots \ldots \ldots \ldots \ldots \ldots$

II.2.B. Gamma-Ray Dose Rates $\ldots \ldots \ldots \ldots \ldots \ldots \ldots \ldots \ldots \ldots$

III. DETAILS OF THE CALCULATIONS $\ldots \ldots \ldots \ldots \ldots \ldots \ldots \ldots \ldots$

III.A. COMPARISONS OF CALCULATED DOSE RATES $\ldots \ldots \ldots \ldots \ldots 7$

III.A.1. Neutron Dose Rates $\ldots \ldots \ldots \ldots \ldots \ldots \ldots \ldots \ldots \ldots$

III.A.2. Gamma-Ray Dose Rates $\ldots \ldots \ldots \ldots \ldots \ldots \ldots \ldots$

IV. COMPARISONS OF MEASURED AND CALCULATED DOSE RATES AND

REDUCTION FACTORS $\ldots \ldots \ldots \ldots \ldots \ldots \ldots \ldots \ldots \ldots \ldots$

IV.A. BD-100R BUBBLE DETECTOR NEUTRON MEASUREMENTS AND CALCULATIONS ....................... 9

IV.A.1. Comparisons with APRF Data $\ldots \ldots \ldots \ldots \ldots \ldots \ldots$

IV.A.2. Comparisons with ETCA Data $\ldots \ldots \ldots \ldots \ldots \ldots \ldots$

iii 
IV.B TLD GAMMA-RAY MEASUREMENTS AND CALCULATIONS $\ldots \ldots 10$

IV.B1. Comparisons with APRF Data $\ldots \ldots \ldots \ldots \ldots \ldots \ldots \ldots \ldots$

IV.B.2. Comparisons with AFRRI Data $\ldots \ldots \ldots \ldots \ldots \ldots \ldots \ldots \ldots$

IV.B.3. Comparisons with HDL Data $\ldots \ldots \ldots \ldots \ldots \ldots \ldots \ldots \ldots$

IV.B.4. Comparisons with ETCA Data $\ldots \ldots \ldots \ldots \ldots \ldots \ldots \ldots \ldots$

V. CONCLUSIONS AND RECOMMENDATIONS $\ldots \ldots \ldots \ldots \ldots \ldots \ldots \ldots$

REFERENCES $\ldots \ldots \ldots \ldots \ldots \ldots \ldots \ldots \ldots \ldots \ldots \ldots \ldots \ldots \ldots \ldots \ldots \ldots \ldots \ldots \ldots \ldots$

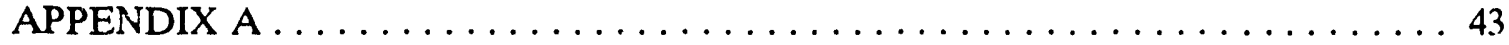




\section{LIST OF TABLES}

Table

Fage

1. Details of the 2-Meter Box and Other Experiment Information $\ldots \ldots \ldots \ldots 2$

2. Details of the RT-200 Canadian Humanoid Phantom $\ldots \ldots \ldots \ldots \ldots \ldots$

3. APRF Measurements of Neutron Dose Rates in the Free-Field and as a Function of Position on the RT-200 Humanoid Phantom. Dose rates in $\operatorname{mrad}_{\mathrm{T} /} / \mathrm{kWh} \ldots \ldots 13$

4. APRF Measurements of Gamma-Ray Dose Rates in the Free-Field and as a Function of Position on the RT-200 Humanoid Phantom. Dose rates in

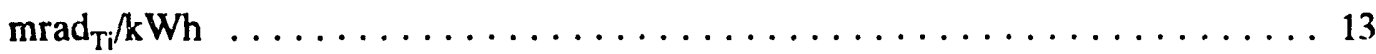

5. AFRRI Measurements of Gamma-Ray Dose Rates in the Free-Field and as a Function of Position on the RT-200 Humanoid Phantom. Dose rates in

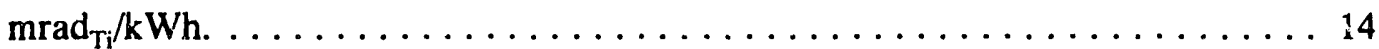

6. HDL Measurements of Gamma-Ray Dose Rates in the Free-Field and as a Function of Position on the RT-200 Humanoid Phantom. Dose rates in

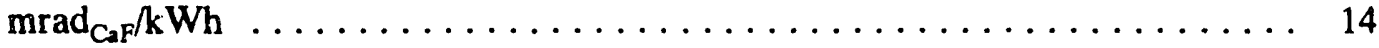

7. ETCA Measurements of Neutron Dose Rates in the Free-Field and as a Function of Position on the RT-200 Humanoid Phantom. Dose rates in

$\operatorname{mrad}_{\mathrm{Ti} /} \mathrm{kWh}$

8. ETCA Measurements of Gamma-Ray Dose Rates in the Free-Field and as a Function of Position on the RT-200 Humanoid Phantom. Dose rates in

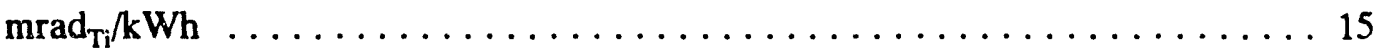

9. Ratios of Measured Neutron Dose Rates $\ldots \ldots \ldots \ldots \ldots \ldots \ldots \ldots \ldots$

10. Ratios of Measured Gamma-Ray Dose Rates. Free-Field, Phantom Facing the Reactor ........................... 6

11. Ratios of Measured Gamma-Ray Dose Rates. In-Box, Phantom Facing the Reactor .............................. 17

12. Ratios of Measured Gamma-Ray Dose Rates. In-Box, Phantom Left Side Facing the Reactor ............................. 18

13. ORNL Calculations of Neutron Dose Rates in the Free-Field and as a Function of Position on the RT-200 Humanoid Phantom. Dose rates in $\operatorname{mrad}_{\mathrm{T}} / \mathrm{kWh} \ldots .19$ 
14. SAIC Calculations of Neutron Dose Rates in the Free-Field and as a Function of Position on the RT-200 Humanoid Phantom. Dose rates in $\operatorname{mrad}_{\mathrm{Ti}} / \mathrm{kWh} \ldots .19$

15. Ratios of Calculated Neutron Dose Rates. Dose rates in $\operatorname{mrad}_{\mathrm{Ti}} / \mathrm{kWh} \ldots \ldots 20$

16. ORNL Calculations of Gamma-Ray Dose Rates in the Free-Field and as a Function of Position on the RT-200 Humanoid Phantom. Dose rates in $\operatorname{mrad}_{\mathrm{Ti}} / \mathrm{kWh}$. . 20

17. SAIC Calculations of Gamma-Ray Dose Rates in the Free-Field and as a Function of Position on the RT-200 Humanoid Phantom. Dose rates in $\operatorname{mrad}_{\mathrm{Ti}} / \mathrm{kWh}$. . 21

18. ORNL Calculations of Gamma-Ray Dose Rates in the Free-Field and as a Function of Position on the RT-200 Humanoid Phantom. Dose rates in $\operatorname{mrad}_{\mathrm{CaF}} / \mathrm{kWh}$. 21

19. SAIC Calculations of Gamma-Ray Dose Rates in the Free-Field and as a Function of Position on the RT-200 Humanoid Phantom. Dose rates in $\operatorname{mrad}_{\mathrm{CaF}} / \mathrm{kWh}$. 22

20. Ratios of Calculated Gamma-Ray Dose Rates. Dose rates in $\operatorname{mrad}_{\mathrm{Ti}} / \mathrm{kWh} \ldots 22$

21. Ratios of the Calculated Gamma-Ray Dose Rates. Dose rates in $\operatorname{mrad}_{\mathrm{CaF}} / \mathrm{kWh} 23$

22. Measured and Calculated Neutron Dose Rates and Reduction Factors. Free-Field, Phantom Facing the Reactor. Comparisons with APRF Measurements. Dose rates

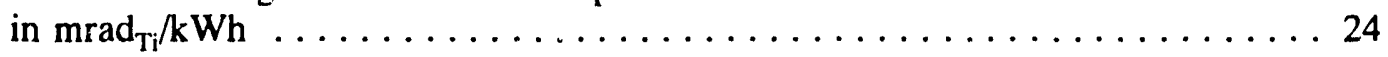

23. Measured and Calculated Neutron Dose Rates and Reduction Factors. In-Box, Phantom Facing the Reactor. Comparisons with APRF Measurements. Dose rates

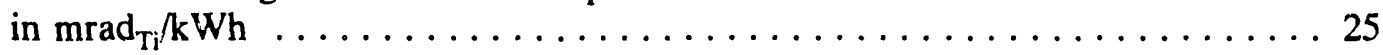

24. Measured and Calculated Neutron Dose Rates and Reduction Factors. In-Box, Phantom Left Side Facing the Reactor. Comparisons with APRF Measurements.

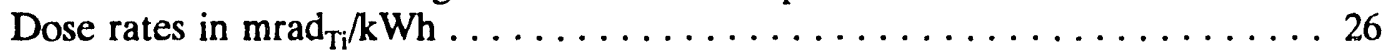

25. Measured and Calculated Neutron Dose Rates and Reduction Factors. Free-Field, Phantom Facing the Reactor. Comparisons with ETCA Measurements. Dose rates

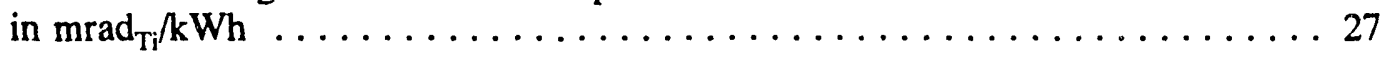

26. Measured and Calculated Neutron Dose Rates and Reduction Factors. In-Box, Phantom Facing the Reactor. Comparisons with ETCA Measurements. Dose rates

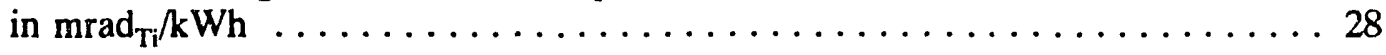

27. Measured and Calculated Neutron Dose Rates and Reduction Factors. In-Box, Phantom Left Side Facing the Reactor. Comparisons with ETCA Measurements.

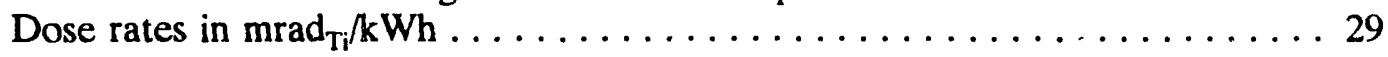


28. Measured and Calculated Gamma-Ray Dose Rates and Reduction Factors. FreeField, Phantom Facing the Reactor. Comparisons with APRF Measurements. Dose

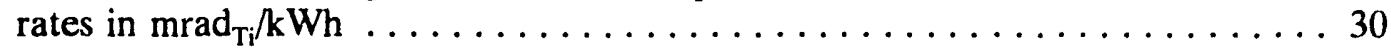

29. Measured and Calculated Gamma-Ray Dose Rates and Reduction Factors. In-Box, Phantom Facing the Reactor. Comparisons with APRF Measurements. Dose rates

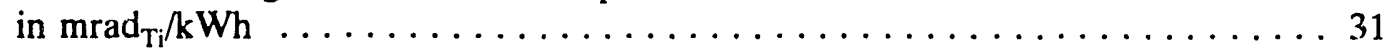

30. Measured and Calculated Gamma-Ray Dose Rates and Reduction Factors. In-Box, Phantom Left Side Facing the Reactor. Comparisons with APRF Measurements.

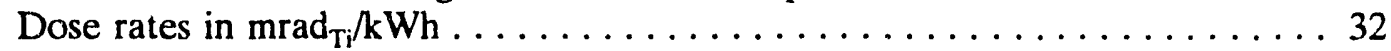

31. Measured and Calculated Gamma-Ray Dose Rates and Reduction Factors. In-Box, Phantom Facing the Reactor. Comparisons with AFRRI Measurements. Dose rates

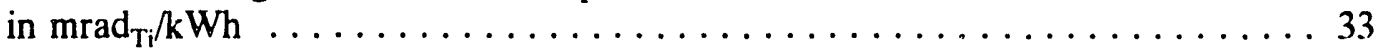

32. Measured and Calculated Gamma-Ray Dose Rates and Reduction Factors. In-Box, Phantom Left Side Facing the Reactor. Comparisons with AFRRI Measurements.

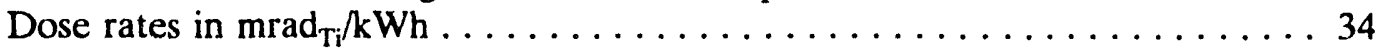

33. Measured and Calculated Gamma-Ray Dose Rates and Reduction Factors. Free-Field, Phantom Facing the Reactor. Comparisons with HDL Measurements. Dose rates

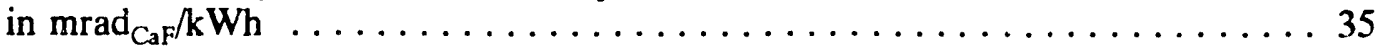

34. Measured and Calculated Gamma-Ray Dose Rates and Reduction Factors. In-Box, Phantom Facing the Reactor. Comparisons with HDL Measurements. Dose rates

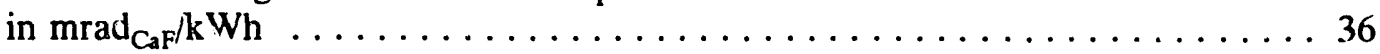

35. Measured and Calculated Gamma-Ray Dose Rates and Reduction Factors. In-Box, Phantom Left Side Facing the Reactor. Comparisons with HDL Measurements.

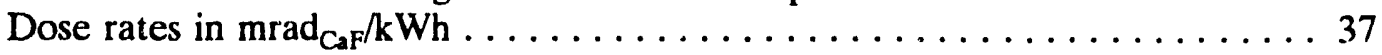

36. Measured and Calculated Gamma-Ray Dose Rates and Reduction Factors. FreeField, Phantom Facing the Reactor. Comparisons with ETCA Measurements. Dose rates in $\operatorname{mrad}_{\mathrm{Ti}} / \mathrm{kWh} \ldots \ldots \ldots \ldots \ldots \ldots \ldots \ldots \ldots \ldots \ldots \ldots \ldots \ldots$

37. Measured and Calculated Gamma-Ray Dose Rates and Reduction Factors. In-Box, Phantom Facing the Reactor. Comparisons with ETCA Measurements. Dose rates

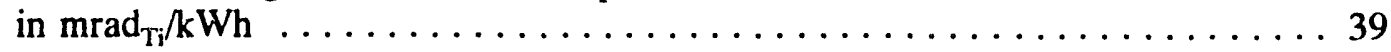

38. Measured and Calculated Gamma-Ray Dose Rates and Reduction Factors. In-Box, Phantom Left Side Facing the Reactor. Comparisons with ETCA Measurements. Dose rates in $\operatorname{mrad}_{\mathrm{Ti}} / \mathrm{kWh} \ldots \ldots \ldots \ldots \ldots \ldots \ldots \ldots \ldots \ldots$ 


\begin{abstract}
This report summarizes the Spring $19912-\mathrm{m}$ Box experiments that were performed at the Army Pulse Radiation Facility (APRF) at Aberdeen Proving Ground. These studies were sponsored by the Defense Nuclear Agency (DNA) under the Radiation Environments Program to obtain measured data for benchmarking the Adjoint Monte Carlo Code System, MASH, Version 1.0. The MASH code system was developed for the Department of Defense and NATO for calculating neutron and gamma-ray radiation fields and shielding protection factors for armored vehicles and military structures against nuclear weapon radiation. In the 2-m Box experiments, neutron and gamma-ray dose rates and reduction factors were measured in the free-field and as a function of position on an anthropomorphic phantom that was placed outside and inside a borated polyethylene lined steel-walled 2-m box. The data were acquired at a distance of $400-\mathrm{m}$ from the APRF reactor. The measurements were performed by APRF, Armed Forces Radiobiology Research Institute (AFRRI), Etablissement Technique Central de l' Armement (ETCA), and Harry Diamond Laboratory (HDL). Calculations were carried out by the Oak Ridge National Laboratory (ORNL) and Science Applications International Corporation (SAIC).
\end{abstract}

The purpose of these experiments was to measure the neutron and gamma-ray dose rates as a function of detector location on the phantom for cases when the phantom was in the free-field and inside of the box. Neutron measurements were made using a BD-100R bubble detector and gamma-ray measurements were made using thermoluminescent detectors (TLD). Calculated and measured data were compared in terms of the C/M ratio. DNA mandated that $\mathrm{C} / \mathrm{M}$ values of $\pm 20 \%$ defined acceptable limits for qualifying the MASH code in replicating integral parameters.

Measurements of the neutron dose rates and reduction factors were carried out by the APRF and ETCA experimentalists. The data reported by each team were in good agreement $( \pm 12 \%)$. The agreement between the calculated and measured neutron dose rates varied with box-phantom geometry but were within the $20 \%$ acceptability limit. The differences between the measured and calculated reduction factors ranged from good to poor depending on the box-phantom geometry with the largest disparity consistently arising for the cases when the phantom was inside the box. Differences in excess of $50 \%$ occurred at specific detector locations. These disparities arise mainly from differences between the measured and calculated free-field dose rates rather than dissimilarities with the in-phantom dose rate values.

Measurements of the gamma-ray dose rates and reduction factors were made by all of the experimental teams. The agreement among the measured data was, in general, within the acceptable range. Large $(>20 \%)$ differences were observed in some cases when the data were compared on a team-by-team basis. The calculated gamma-ray dose rates and reduction factors were in good agreement with the data acquired by each experimental team.

The calculated and ineasured neutron and gamma-ray dose rates and reduction factors agreed on the average within the $\pm 20 \%$ limits mandated by DNA and demonstrate the capability of the MASH code system in reproducing measured data in nominally shielded assemblies. 


\section{INTRODUCTION}

As part of the Radiation Environments Program (REP) sponsored by the Defense Nuclear Agency (DNA), a series of "benchmark" experiments were performed at the Army Pulse Radiation Facility (APRF) at Aberdeen Proving Grounds. The purpose of these experiments was to measure neutron and gamma-ray differential and integral spectra, kerma, and dose in the free-field and inside a cubical shaped steel-walled box located at a distance of 400 meters from the APRF reactor. The experiments were performed for different box configurations, i.e., unlined and lined and with and without a phantom positioned inside the box. The box configuration has been accepted as the "NATO standard test bed" and the 400 meter reactor-to-box distance is defined as the "NATO standard reference point". Measured data were obtained by experimentalists from different organizations that participate in the REP. The measured data are being used to benchmark the Monte Carlo Adjoint Shielding code system - MASH ${ }^{(1)}$ that is being validated under this effort. MASH was developed to replace the Vehicle Code System (VCS) ${ }^{(23)}$ for estimating radiation effects inside armored vehicles and other shielded configurations of interest to the military.

In previous reports (Refs 4-8), measured and calculated data were compared for experiments that were performed in the Fall of 1989 and the Spring of 1990. In the 1989 study, spectra and kerma (dose) were measured using different types of detectors placed in the free-field and inside the 2-meter box. In the 1990 study, neutron and gamma-ray dose was measured in the free-field and at several positions on an anthropomorphic phantom that was either in the free-field or inside the 2-m box. This report summarizes the last in the series of these experiments: the Spring 1991 experiments that were periormed during the period 30 April - 9 May $1991 .^{(9)}$

Measurements of neutron and gamma-ray dose as a function of position on an RT-200 Canadian Humanoid Phantom ${ }^{(10)}$ (hereafter referred to as the phantom) positioned in the standing posture in the free-field and in the center of the 2-meter box for different boxphantom orientations were carried out at the APRF. These measurements differ from those reported in the Spring 1990 investigation in that the box was lined with 5.08-cm-thick borated polyethylene (5\% boron). Neutron and gamma-ray dose data were obtained by experimentalists from the APRF, the Armed Forces Radiobiolog Research Institute (AFRRI), Harry Diamond Laboratory (HDL), and the Establissement Technique Central de l'Armement (ETCA). Calculations were performed by analysts from the Oak Ridge National Laboratory (ORNL) and Science Applications International Corporation (SAIC). The organizations and scientists that participated in this study are identified in Appendix A .

Details of the Spring 1991 experiments and comparisons among the data obtained by the experimental teams are presented in Section II. The calculated data reported by ORNL and SAIC are compared and discussed in Section III. The measured and calculated data are compared in Section IV while the conclusions, observations, and recommendations resulting from this study are presented in Section V. 


\section{DETAILS OF THE MEASUREMENTS}

The 2-meter box assembly used in the Spring 1991 study was the same as that used in the 1989 and 1990 investigations and described in Refs. 4-8. For this study, however, the box was lined with $5.08 \mathrm{~cm}$ of borated polyethylene (5\% boron). Measurements and calculations of neutron and gamma-ray dose were made as a function of detector position on the body of a humanoid phantom. The phantom was always in the standing position either in the free-field or inside the box. In all of the measurements, one face of the box was always perpendicular to the reactor- $400 \mathrm{~m}$-test site axis. The phantom was positioned inside the box either facing the reactor or turned 90-degrees with the left shoulder facing the radiation source. In the free-field measurements, the phantom was facing the reactor. Details of the $2-m$ box and other information concerning the experiments are summarized in Table 1 . The RT-200 phantom, including its dimensions, material composition, ${ }^{(10)}$ and the locations on the phantom where dose rates were measured are described in Table 2.

Table 1. Details of the 2-Meter Box and Other Experiment Information.

\begin{tabular}{cc|cc}
\hline \multicolumn{2}{c|}{ 2-Meter Box } & \multicolumn{2}{c}{ Box Disposition } \\
\hline \hline Shape & Cubic & Reactor to Box & $400 \mathrm{~m}$ \\
Interior Dimensions & $2.0 \mathrm{~m}$ & 400 -m Site Elevation & $10.45 \mathrm{~m}$ \\
Wall Thickness & $0.1016 \mathrm{~m}$ & $\begin{array}{c}\text { Reactor Pad } \\
\text { Elevation }\end{array}$ & $13.58 \mathrm{~m}$ \\
Wall Material & Steel & $\begin{array}{c}\text { Reactor Center } \\
\text { Elevation }\end{array}$ & $26.78 \mathrm{~m}$ \\
Liner Material & Borated Polyethylene & & \\
& $(5 \%$ Boron) & & \\
\hline \hline
\end{tabular}

Ground contour and terrain details, including the position of the reactor relative to the 400 meter test site, were the same as those in the Fall 1989 and Spring 1990 investigations and reported in Refs. 4-8. Atmospheric conditions (air temperature, barometric pressure, and relative humidity) and soil moisture content were monitored and recorded by the APRF staff during the measurements. Meteorological data recorded during the measurements are summarized in Ref. 11. The meteorological data are mean values obtained from observations taken at regular intervals during the course of these measurements. The soil moisture content during all experiments was relatively ronstant; of the order of $35 \%$ by weight of dry soil. In all cases, the reactor was operated at steady state power levels and run durations sufficient to assure acceptable statistical accuracy in the measured data. 
Table 2. Details of the RT-200 Canadian Humanoid Phantom.

\begin{tabular}{|c|c|c|c|c|c|c|}
\hline & \multicolumn{3}{|c|}{ Composition } & \multicolumn{3}{|c|}{$\begin{array}{c}\text { Physical } \\
\text { Parameters }\end{array}$} \\
\hline Element & Lung & Tissue & Bone & & & \\
\hline \multicolumn{7}{|c|}{$\left(\right.$ atoms $\left./ \mathrm{cm}^{3}\right)$} \\
\hline $\mathrm{H}$ & $1.65 \times 10^{-2}$ & $5.88 \times 10^{-2}$ & $6.14 \times 10^{-2}$ & Height & & $175 \mathrm{~cm}$ \\
\hline $\mathrm{C}$ & $1.18 \times 10^{-2}$ & $3.36 \times 10^{-2}$ & $1.78 \times 10^{-2}$ & Chest & (Depth) & 21.4 \\
\hline $\mathrm{N}$ & $1.02 \times 10^{-3}$ & $1.98 \times 10^{-3}$ & $1.84 \times 10^{-3}$ & Chest & (Width) & 33.8 \\
\hline $\mathrm{O}$ & $3.82 \times 10^{-3}$ & $7.72 \times 10^{-3}$ & $2.52 \times 10^{-2}$ & Head & (Depth) & 20.8 \\
\hline $\mathrm{Na}$ & $1.74 \times 10^{-9}$ & $2.32 \times 10^{-7}$ & $1.20 \times 10^{-4}$ & Head & (Width) & 14.8 \\
\hline $\mathrm{Mg}$ & $7.13 \times 10^{-8}$ & & $3.88 \times 10^{-5}$ & Mass & & $74 \mathrm{~kg}$ \\
\hline $\mathrm{Al}$ & \multicolumn{3}{|c|}{$2.29 \times 10^{-9}$} & \multicolumn{3}{|c|}{$\begin{array}{l}\text { Locations on the Phantom where Dose } \\
\text { rates were Measured. }\end{array}$} \\
\hline $\mathrm{Si}$ & & & $6.00 \times 10^{-7}$ & Free & (FF) & Out \\
\hline $\mathbf{P}$ & & & $4.54 \times 10^{-5}$ & & & Box \\
\hline$S$ & & & $4.54 \times 10^{-5}$ & & & $\mathrm{MH}$ \\
\hline $\mathrm{Cl}$ & & $2.35 \times 10^{-8}$ & $3.40 \times 10^{-5}$ & & & MG \\
\hline $\mathrm{K}$ & & & $2.30 \times 10^{-3}$ & & est & LC \\
\hline $\mathrm{Ca}$ & & & $2.14 \times 10^{-3}$ & & rist & LW \\
\hline \multirow[t]{3}{*}{$\mathrm{Fe}$} & & & $1.20 \times 10^{-6}$ & & rist & RW \\
\hline & & & & & elt & FB \\
\hline & & & & & elt & $\mathrm{BB}$ \\
\hline
\end{tabular}


Three box-phantom orientations were studied in the measurements:

A. Free-field Measurements. Phantom standing at a distance of 10-m from the box facing the reactor.

B. In-Box Measurements. Phantom in standing position in the 2-m box facing the reactor.

C. In-Box Measurements. Phantom standing in the 2-m box with the left shoulder facing the reactor.

Measurements were also made of the free-field dose rates and the attenuated dose rate in the box. The free-field dose rate was measured by placing dosimeters at a distance of $5.40-\mathrm{m}$ to the side of the $2-\mathrm{m}$ box at a height of $1.15 \mathrm{-m}$ above the ground and distance of 400 $\mathrm{m}$ from the reactor. The attenuated dose (hereafter referred to as the box dose) was measured by placing dosimeters inside the $2-\mathrm{m}$ box at a height above the floor of the box of $0.68-\mathrm{m}$ and at a distance of $0.70-\mathrm{m}$ from the axis of symmetry of the box, i.e. alongside the phantom when the phantom was in the box.

\section{II.A. APRF MEASUREMENTS}

The APRF team measured both neutron and gamma-ray dose rates as a function of detector location on the phantom for the three box-phantom orientations described above. The neutron dose rates were obtained using BD-100R bubble detectors manufactured by Bubble Technology Industries ${ }^{(12)}$. Gamma-ray dose rates were obtained using Harshaw $\mathrm{CaF}_{2}: \mathrm{Mn}$ thermoluminescent detectors ${ }^{(11)}$ (TLD). Complete descriptions of these detectors, calibration procedures, conversion factors, and other details of the measurements may be found in Refs 10 and 11.

The neutron and gamma-ray dose rates reported by the APRF team are summarized in Tables 3 and 4 , respectively. The dose rates reported in the tables, and throughout this report, are in units of mrad (Tissue) per kilowatt hour ( $\mathrm{kWh}$ ).

\section{II.B. AFRRI MEASUREMENTS}

The AFRRI team used Victoreen Model 2600-80 Aluminum Oxide TLD dosimeters to measure gamma-ray dose rates. ${ }^{(13)}$ AFRRI investigators did not measure neutron dose rates. Measurements were made for the two box-phantom configurations where the phantom was inside of the $2-\mathrm{m}$ box. No data were obtained for the case when the phantom was standing in the free-field. The results of the AFRRI measurements, in units of mrad (Tissue) per kilowatt hour $(\mathrm{kWh})$, are summarized in Table 5. 


\section{II.C. HDL MEASUREMENTS}

The HDL also only measured gamma-ray dose rates using $\mathrm{CaF}_{2}: \mathrm{Mn}$ thermoluminescent dosimeters (Harshaw TLD-400) ${ }^{(14)}$. To achieve greater sensitivity, HDL employed TLD's having a volume eight times greater than the TLD dosimeters used by the APRF, AFRRI, and ETCA teams. For the free field measurements, the TLD's were enclosed in $1 \mathrm{~g} / \mathrm{cm}^{2}$-thick aluminum capsules. For the phantom measurements, the dosimeters were wrapped in four layers of $25 \mu \mathrm{m}$-thick aluminum foil. HDL corrected all TLD measurements to account for the effects on the dose of thermal neutrons.

The procedures used by HDL are summarized in Reference 14 and the gamma-ray dose rate measurements are summarized in Table 6 . Note that the HDL investigators reported the dose rates in units of $\operatorname{mrad}\left(\mathrm{CaF}_{2}\right)$ per $\mathrm{kWh}$. The dose rates given in Table 6 must be multiplied by a factor of 1.149 to convert to units of mrad (Tissue) per $\mathrm{kWh}$ for direct comparison with the results reported by APRF, AFRRI, and ETCA.

\section{II.D. ETCA MEASUREMENTS}

The ETCA team, like the APRF team, also measured neutron and gamma-ray dose rates in the free-field and on the phantom for all three box-phantom configurations. ${ }^{(15)}$ The neutron dose rates were measured using bubbie detectors manufactured by Bubble Technology Industries and the gamma-ray dose rates were measured using Harshaw $\mathrm{CaF}_{2}: \mathrm{Mn}$ thermoluminescent detectors. ${ }^{(14)}$

The neutron and gamma-ray dose rates measured by ETCA are summarized in Tables 7 and 8 , respectively.

\section{I.2. COMPARISONS OF MEASURED DOSE RATES}

The dose rates reported by each experimental team are compared in terms of the ratios of the measured $(\mathrm{M})$ data: i.e., $\left(\mathrm{M}_{\text {Team 1 }} / \mathrm{M}_{\text {Team 2 }}\right)$ ratios for the various free-field and phantom TLD locations. DNA adopted the criterion that the range of acceptability for comparisons of measured and calculated neutron and gamma-ray data was $\pm 20 \%$.

\section{II.2.A. Neutron Dose Rates}

The neutron dose rates measured by the APRF and ETCA teams are compared in terms of the APRF/ETCA ratios in Table 9. The dose rates are compared at all detector locations for the three box-phantom configurations. Also given in the table are the averages of the ratios and the standard deviation of the average values. For most of the detector locations, the neutron dose rates measured by each team agree within $\pm 20 \%$. The largest differences occur at the back-belt (BB) detector position where the dose rates vary by as much as $56 \%$. The ratios of the averages of the dose rates over detector locations on the phantom indicate consistency among the data within $12 \%$. These results suggest congruent 
application of the bubble detectors and interpretation of the measured data.

\section{II.2.B. Gamma-Ray Dose Rates}

The gamma-ray dose rates measured by APRF, HDL, and ETCA for the case when the phantom was in the free-field facing the reactor are compared in Table 10. The dose rates measured by these teams are in good agreement at most of the detector locations. Exceptions occur for the FF Box locations where the APRF and HDL results difier by $26 \%$ and the HDL and ETCA dose rates differ by $47 \%$ The averages of dose rates in the phantom are, in all cases, in good agreement and exhibit small $(<10 \%)$ deviations among the ratios.

The comparisons of the measured dose rates for the cases where the phantom was in the box facing the reactor and with the left shoulder facing the reactor, are summarized in Tables 11 and 12, respectively. All of the experimental teams collected data for these boxphantom orientations. The measured gamma-ray dose rates are, again, in reasonably good agreement for all detector locations. For the case when the phantom is facing the reactor, the largest differences are among data reported by AFRRI, HDL, and ETCA. The AFRRI team reports iower $(>20 \%)$ dose rates than HDL at all detector locations. While HDL reports larger dose rates than ETCA at the back-belt (BB), left-chest (LC), mid-head (MH), and mid-gut (MG) detector locations in the phantom. In the case when the phantom is in the box, left-side facing the reactor, acceptable ratios are achieved at all detector locations except at the left-wrist (LW), right-wrist (RW), and mid-gut (MG) detector locations. HDL and ETCA achieve somewhat better agreement among the data compared to the previous case where the phantom is facing the reactor except at the back-belt (BB) detector location where the dose rates differ by $33 \%$. 


\section{DETAILS OF THE CALCULATIONS}

Analyses of the 2-m box-phantom experiments were carried out separately by researchers from the Oak Ridge National Laboratory (ORNL) and Science Applications International Corporation (SAIC). Both teams used the MASH code to estimate the dose rates in the free-field and at detector locations on the phantom for the three experiment configurations described in the previous section. The purpose of conducting two separate analyses was to provide a cross-check of the analytic results and to assure a consistent application of the MASH code system in the benchmarking process.

All of the calculations were performed using the MASH code system, Version $1.0^{(1)}$ that is maintained on the Los Alamos National Laboratory (LANL) CRAY computer. At present, this is the only authorized version of the code system. The transport calculations were carried out using the DABL69 (ENDF/B-V) cross-section library ${ }^{(16)}$ that is also maintained on the LANL CRAY computer. The experimental geometry, including the 2-m box and the RT-200 Phantom were replicated in detail using the combinatorial geometry options in the MASH code system. The box and phantom geometries are described in detail in Refs. 4, 8, and 9 ORNL and SAIC used slightly different approaches to calculate the dose rates but each approach was within the existing capability of the MASH code system.

Air-over-ground calculations used to estimate the neutron and gamma-ray fluence in $t^{\prime}$ 'se free-field and on a coupling surface surrounding the box took into account the air and soil moisture content at the time of the measurements. The Monte Carlo (MORSE) calculations to determine the dose rates at the detector positions on the phantom both inside and outside the box generated and tracked a sufficiently large number of primary source particles to assure adequate sampling over all energy groups. Energy dependent relative importance factors were used to increase the frequency of sampling the adjoint source particles from energy groups having the most significant effect on the dose response function. The secondary particle production probability was set to 1.0 for all regions and energy groups and the in-group energy biasing option in MORSE was turned on for all calculations. Region dependent and energy independent splitting and Russian Roulette parameters were used to improve the statistical accuracy of the Monte Carlo calculations. These options produced an escaping particle to source particle ratio of nominally one.

Statistical uncertainties on the integral neutron and gamma-ray dose rates were consistently less than $3 \%$ for all calculations.

\section{III.A. COMPARISONS OF CALCULATED DOSE RATES}

The calculated neutron and gamma-ray dose rates are presented and compared in this section in terms of the $\mathrm{C}_{\text {ORNI }} / \mathrm{C}_{\text {SAIC }}$ ratio. 


\section{III.A.1. Neutron Dose Rates}

The neutron dose rates calculated by ORNL and SAIC for the three-box phantom configuration are given in Tables 13 and 14, respectively. These data are compared in terms of the ratio ORNL/SAIC in Table 15 . Both analytic teams consistently calculate the neutron dose rates within the accepted $\pm 20 \%$ tolerance at all detector locations except for the two cases, FF box location when the phantom is in the free-field and at the mid-gut (MG) detector location when the phantom is in the box with the left shoulder facing the reactor. For the FF box detector location, the calculations differ by $33 \%$ and for the MG detector location the calculated dose rates differ by $25 \%$ with ORNL reporting lower values than SAIC. Considering that most of the calculated neutron dose rates agree within $\pm 10 \%$, the disagreement in the dose rates calculated at these two detector locations should be treated as atypical.

\section{III.A.2. Gamma-Ray Dose Rates}

The gamma-ray dose rates calculated by ORNL and SAIC as a function of detector location in the box and on the phantom are summarized in Tables 16-19. Table 16 and 17 report the calculated dose rates in units of mrad (Tissue) per $\mathrm{kWh}$ for comparisons with the APRF, AFRRI, ETCA and TLD measurements. The data in Tables 18 and 19 summarize the dose rates in units of mrad $\left(\mathrm{CaF}_{2}\right)$ per $\mathrm{kWh}$ for comparion with the $\mathrm{HDL}$ measurements.

Table 20 compares the calculated gamma-ray dose rates given in Tables 16 (ORNL) and 17 (SAIC) in terms of the ratio, ORNL/SAIC. The ratios of the dose rates in Tables 18 and 19 are similarly compared in Table 21 . The gamma-ray dose rates calculated by both analytic teams are in very good agreement at all detector locations.

The generally excellent agreement between the data reported by ORNL and SAIC for both neutron and gamma-ray dose rates indicate that the analysts consistently replicated the experimental configuration, reactor source term, and meteorologic conditions and applied the MASH code system and data in essentially the same way. 


\section{COMPARISONS OF MEASURED AND CALCULATED DOSE RATES AND REDUCTION FACTORS}

To facilitate the comparisons of the measured and calculated dose rates and reduction factors, the analytic results are compared with the measured results separately as a function of experiment team and box-phantom configuration. Given in the following tables are the measured and calculated dose rates and reduction factors and the calculated-tomeasured, $\mathrm{C} / \mathrm{M}$, ratios. Also given in the tables are the averages of the measured and calculated dose rates and reduction factors and $\mathrm{C} / \mathrm{M}$ ratios for the seven detector locations on the phantom.

\section{IV.A. BD-100R BUBBLE DETECTOR NEUTRON MEASUREMENTS AND CALCULATIONS}

\section{IV.A.1. Comparisons with APRF Data}

The measured neutron dose rates and reduction factors obtained by the APRF team for the three box-phantom configurations are compared with the corresponding calculated data reported by ORNL and SAIC in Tables 22-24. The dose rates are compared in units of mrad (Tissue) per $\mathrm{kWh}$. In Table 22, data are compared for the case when the phantom is standing in the free-field. Note that the calculated dose rates are higher than the measured values at all detector locations. An exception occurs at the mid-head (MH) location where SAIC obtains a lower value than the measured dose rate. ORNL and SAIC calculate freefield detector dose rates that are $\sim 17 \%$ larger than the APRF measurements. The C/M values for the dose rates as a function of detector location in the phantom indicate $5 \%$ to $36 \%$ overestimates of the calculated data. When these data are averaged over all in-phantom positions, the calculations are still higher than the measurements by $\sim 17 \%$. Examination of the reduction factors show more favorable agreement at all detector locations in the phantom as well as for the average values.

For the two cases when the phantom is in the box, the results in Tables 23 and 24 show a reversal in the behavior of the calculated and measured dose rates and reduction factors. For these cases, the calculations overestimate the free-field detector dose rates and underestimate, on the average, the dose rates as a function of detector location in the phantom. Correspondingly, the calculated neutron reduction factors are larger than the measured values at all detector locations.

\section{IV.A.2. Comparisons with ETCA Data}

The calculated neutron dose rates and reduction factors are compared with the ETCA measurements in Tables 25-27. For the case when the phantom is in the free-field, Table 25, the calculated and measured dose rates and reduction factors are in rather good agreement. Exceptions occur at the right-wrist (RW) position where ORNL overestimates the dose rate 
measured by ETCA by $26 \%$ and SAIC calculates a value $17 \%$ higher than the measurement. These values exceed one standard deviation the average dose rates. Note also that SAIC also calculates a much higher value for the dose rate for the in box detector. The $\mathrm{C} / \mathrm{M}$ values for the reduction factors are within the $\pm 20 \%$ acceptability tolerance except for the left-wrist (LW) location where the SAIC value is only slightly higher $(21 \%)$.

For the cases when the phantom is inside the box, shown in Tables 26 and 27, the agreement between the measured and calculated dose rates in the phantom are, for the most part, quite acceptable. Exceptions occur at the back-belt (BB) location when the phantom is facing the reactor and the mid-head (MH) location when the left side of the phantom is facing the reactor. In the former case, SAIC overestimates the BB dose by $31 \%$ and in the latter case ORNL underestimates the $\mathrm{MH}$ dose by $33 \%$.

The differences in the calculated and free-field detector dose rates vary widely for the three box-phantom configurations - C/M values vary between $27 \%$ and $54 \%$.

The calculated reduction factors for the cases when the phantom is in the box shown in Tables 26 and 27, are much greater than the values calculated by ETCA at all detector locations.

\section{IV.B TLD GAMMA-RAY MEASUREMENTS AND CALCULATIONS}

\section{IV.B.1. Comparisons with APRF Data}

The gamma-ray dose rates and reduction factors measured by the APRF team are compared with the calculated data reported by ORNL and SAIC for the three box-phantom configurations in Tables 28-30. The agreement between the measured and calculated results are, in all cases, very good and well within the C/M tolerance of $\pm 20 \%$. Exceptions occur in Table 28 where $\mathrm{C} / \mathrm{M}$ values for the box reduction factors are marginal, in Table 29 where SAIC underestimates the box and back-belt (BB) reduction factors, and in Table $\mathbf{3 0}$ where the SAIC value for reduction factor for the left-chest (LC) detector is $27 \%$ lower than the measured value. These exceptions are noted only because they fall outside the limit of acceptability and not because they represent significant differences between the measured and calculated dose rates and reduction factors.

\section{IV.B.2. Comparison with AFRRI Data}

The calculated dose rates and reduction factors are compared with the AFRRI TLD measurements in Tables 31 and 32. AFRRI made measurements for the in-box phantom configurations only. ORNL and SAIC consistently overestimate the dose rates at all detector locations. The $\mathrm{C} / \mathrm{M}$ values range from acceptable to marginal and in a few cases, i.e. the leftchest (LC), left wrist (LW), and mid-head (MH) detector locations for the phantom in the box, left shoulder facing the reactor, the analysts overestimate the doses by as much as $35 \%$. The calculated and measured reduction factors for both configurations are generally in good 
agreement $(\leq 20 \%)$ at all detector locations.

\section{IV.B.3. Comparisons with HDL Data.}

The gamma-ray dose rates and reduction factors measured by HDL are compared with the calculated data in Tables 33-35. Note that dose rate data are in units of $\mathrm{mrad}\left(\mathrm{CaF}_{2}\right)$ per $\mathrm{kWh}$. For the case when the phantom was in the free-field, both ORNL and SAIC overestimate the dose rates in all detector locations except for the detector in the box and at the left-wrist (LW) location where ORNL underestimates the dose. The calculated and measured reduction factors are in good agreement at all locations.

For the cases when the phantom was in the box, the agreement between the measured and calculated dose rates and reduction factors are generally good. The largest differences occur at the mid-head $(\mathrm{MH})$ detector location, phantom facing the reactor, where the value of the $\mathrm{C} / \mathrm{M}$ exceeds $30 \%$. For the case when the phantom's left shoulder is facing the reactor, ORNL and SAIC both overestimate the dose rate at the front-belt (FB) detector location.

\section{IV.B.4. Comparisons with ETCA Data.}

The dose rates and reduction factors measured by ETCA are compared with the calculated data in Tables 36-38. The $\mathrm{C} / \mathrm{M}$ values indicate very good agreement among the data at all detector locations for all three box-phantom experiment configurations. 


\section{CONCLUSIONS AND RECOMMENDATIONS}

The authors of this document were tasked by the DNA to document the results of this study and to compare the measured and calculated data in an unbiased manner. No attempt was made to screen inconsistent data or otherwise intervene with the data by reconciling or recalculating dose rates or reduction factors. In attempting to determine the capability of the MASH code system in replicating the Spring 1991 experiments, it was determined that the optimum course was to survey the measured and calculated data on a case-by-case and teamsby-team basis and summarize the results.

The results presented in the tables display agreement between the measured and calculated neutron and gamma-ray doses and reduction factors that range from very good to marginal depending on the experiment configuration, detector location, and the experimental or analytic team reporting the results.

Measurements of the neutron dose rates and reduction factors were made by the APRF and ETCA experimentalists only. The data reported by each team were in good agreement $( \pm 12 \%)$. The agreement between the calculated and measured neutron dose rates varied with box-phantom geometry but were generally weli within the $20 \%$ acceptability limit. The differences between the measured and calculated reduction factors ranged from good to poor depending on the box-phantom geometry with the largest disparity consistently arising for the cases when the phantom was inside the box. Differences in excess of $50 \%$ occurred at specific detector locations. These disparities arise mainly from differences between the measured and calculated free-field dose rates rather than very dissimilar results in the inphantom dose rate value. ${ }^{(17)}$

Measurements of the gamma-ray dose rates and reduction factors were made by all of the experiment teams. The agreement among the measured data was, in general, within the acceptable range. Large $(>20 \%)$ differences were observed in some cases when the data were compared on a team-by-team basis. The calculated gamma-ray dose rates and reduction factors were in good agreement with the data acquired by each experimental team.

The principal purpose for developing the MASH code system was to provide the U.S. Army and in particular the U.S. Army Nuclear and Chemical Agency (USANCA) with the capability to calculate reduction factors of armored vehicle shielding materials against neutron and gamma-rays produced in nuclear weapon explosions. The $\mathrm{C} / \mathrm{M}$ results obtained here show that the MASH code is capable of replicating integral dose data within accepted tolerances and that MASH version 1.0 can be used to estimate neutron and gamma-ray reduction factors for armored vehicles and other shielded configurations having shield thicknesses and compositions similar to those used in these box studies. 
Table 3. APRF Measurements of Neutron Dose Rates in the Free-Field and as a Function of Position on the RT-200 Humanoid Phantom.

Dose rates in $\operatorname{mrad}_{\mathrm{Ti}} / \mathrm{kWh}$.

\begin{tabular}{ccccc}
\hline RUN NUMBER & & 128 & 113 & 120 \\
\hline \hline FF DOSE & OUTSIDE & 4.26 & 3.88 & 3.88 \\
& FF & IN-BOX & IN-BOX \\
& FF BOX & & 0.37 & 0.36 \\
\hline DOSE PHANTOM & BB & 1.20 & 0.25 & 0.35 \\
& LC & 3.72 & 0.37 & 0.32 \\
& LW & 3.60 & 0.35 & 0.36 \\
& RW & 3.91 & 0.38 & 0.27 \\
& MH & 1.16 & 0.13 & 0.12 \\
& MG & 0.65 & 0.06 & 0.03 \\
\hline \hline
\end{tabular}

Table 4. APRF Measurements of Gamma-Ray Dose Rates in the Free-Field and as a Function of Position on the RT-200 Humanoid Phantom.

Dose rates in $\mathrm{mrad}_{\mathrm{T}} / \mathrm{kWh}$.

\begin{tabular}{ccccc}
\hline RUN NUMBER & & $130 / 131$ & 123 & $121 / 122$ \\
\hline \hline FF DOSE & & $\begin{array}{c}\text { FF } \\
\text { FACING }\end{array}$ & $\begin{array}{c}\text { IN-BOX } \\
\text { FACING }\end{array}$ & $\begin{array}{c}\text { IN-BOX } \\
\text { LEFT SIDE }\end{array}$ \\
\hline & OUTSIDE & 1.49 & 1.48 & 1.47 \\
& FF BOX & 0.35 & 0.34 & 0.34 \\
\hline DOSE IN PHANTOM & FB & 2.02 & 0.38 & 0.35 \\
& BB & 1.45 & 0.30 & 0.34 \\
& LC & 2.05 & 0.41 & 0.38 \\
& LW & 1.82 & 0.34 & 0.36 \\
& RW & 1.82 & 0.35 & 0.30 \\
& MH & 2.03 & 0.41 & 0.41 \\
& MG & 2.04 & 0.37 & 0.36 \\
\hline \hline
\end{tabular}


Table 5. AFRRI Measurements of Gamma-Ray Dose Rates in the Free-Field and as a Function of Position on the RT-200 Humanoid Phantom.

Dose rates in $\operatorname{mrad}_{\mathrm{Ti}} / \mathrm{kWh}$.

\begin{tabular}{cccc}
\hline RUN NUMBER & & 123 & $121 / 122$ \\
\hline \hline FF DOSE & & $\begin{array}{c}\text { IN-BOX } \\
\text { FACING }\end{array}$ & $\begin{array}{c}\text { IN-BOX } \\
\text { LEFT SIDE }\end{array}$ \\
\hline & OUTSIDE & 1.23 & 1.24 \\
& FF BOX & 0.30 & 0.29 \\
\hline \multirow{2}{*}{ DOSE IN PHANTOM } & FB & 0.33 & 0.33 \\
& BB & 0.28 & 0.32 \\
& LC & 0.33 & 0.34 \\
& LW & 0.30 & 0.31 \\
& RW & 0.31 & 0.26 \\
& MH & 0.35 & 0.34 \\
& MG & 0.31 & 0.29 \\
\hline \hline
\end{tabular}

Table 6. HDL Measurements of Gamma-Ray Dose Rates in the Free-Field and as a Function of Position on the RT-200 Humanoid Phantom. Dose rates in $\operatorname{mrad}_{\mathrm{CaF}} / \mathrm{kWh}$.

\begin{tabular}{ccccc}
\hline RUN NUMBER & & $130 / 131$ & 123 & $121 / 122$ \\
\hline \hline FF DOSE & & FF & IN-BOX & IN-BOX \\
& OUTSIDE & 1.23 & 1.23 & 1.23 \\
& FF BOX & 0.41 & 0.32 & 0.31 \\
\hline \multirow{2}{*}{ DOSE IN PHANTOM } & FB & 1.65 & 0.40 & 0.30 \\
& BB & 1.30 & 0.34 & 0.37 \\
& LC & 1.61 & 0.43 & 0.34 \\
& LW & 1.58 & 0.36 & 0.38 \\
& RW & 1.43 & 0.32 & 0.35 \\
& MH & 1.72 & 0.51 & 0.35 \\
& MG & 1.75 & 0.41 & 0.34 \\
\hline \hline
\end{tabular}


Table 7. ETCA Measurements of Neutron Dose Rates in the Free-Field and as a Function of Position on the RT-200 Humanoid Phantom.

Dose rates in $\operatorname{mrad}_{\mathrm{Ti}} / \mathrm{kWh}$.

\begin{tabular}{ccccc}
\hline \hline RUN NUMBER & & 128 & 113 & 120 \\
\hline \hline FF DOSE & OUTSIDE & 4.78 & 3.51 & 4.15 \\
& FF & IN-BOX & $\begin{array}{c}\text { IN-BOX } \\
\text { LEFT SIDE }\end{array}$ \\
\hline \multirow{2}{*}{ DOSE IN PHANTOM } & FB & 0.37 & 0.41 & 0.33 \\
& BB & 4.46 & & \\
& 1.55 & 0.16 & 0.29 \\
& LC & 4.24 & 0.39 & 0.32 \\
& LW & 4.74 & 0.37 & 0.38 \\
& RW & 3.52 & 0.37 & 0.25 \\
& MH & 1.22 & 0.12 & 0.15 \\
& MG & 0.80 & 0.06 & 0.04 \\
\hline \hline
\end{tabular}

Table 8. ETCA Measurements of Gamma-Ray Dose Rates in the Free-Field and as a Function of Position on the RT-200 Humanoid Phantom.

Dose rates in $\operatorname{mrad}_{\mathrm{Ti}} / \mathrm{kWh}$.

\begin{tabular}{ccccc}
\hline RUN NUMBER & & $130 / 131$ & 123 & $121 / 122$ \\
\hline \hline FF DOSE & OUTSIDE & 1.39 & 1.38 & 1.30 \\
& FF & IN-BOX & $\begin{array}{c}\text { IN-BOX } \\
\text { LEFT SIDE }\end{array}$ \\
\hline \hline \multirow{2}{*}{ FOSE IN PHANTOM } & FB & 0.32 & 0.38 & 0.36 \\
& FBCING & 1.82 & & \\
& BB & 1.43 & 0.35 & 0.32 \\
& LC & 1.77 & 0.40 & 0.35 \\
& LW & 1.52 & 0.38 & 0.36 \\
& RW & 1.50 & 0.34 & 0.37 \\
& MH & 1.86 & 0.44 & 0.41 \\
& MG & 1.81 & 0.34 & 0.36 \\
\hline \hline
\end{tabular}


Table 9. Ratios of Measured Neutron Dose Rates.

\begin{tabular}{|c|c|c|c|c|}
\hline \multirow[t]{3}{*}{ RUN NUMBER } & & 128 & 113 & 120 \\
\hline & & $\begin{array}{c}\text { FF } \\
\text { FACING }\end{array}$ & $\begin{array}{l}\text { IN-BOX } \\
\text { FACING }\end{array}$ & $\begin{array}{c}\text { IN-BOX } \\
\text { LEFT-SIDE }\end{array}$ \\
\hline & & APRF/ETCA & APRF/ETCA & APRF/ETCA \\
\hline \multirow[t]{2}{*}{ FF DOSE } & OUTSIDE & 0.89 & 1.11 & 0.93 \\
\hline & FF BOX & & 0.90 & 1.09 \\
\hline \multirow[t]{8}{*}{ DOSE IN PHANTOM } & $\mathrm{BB}$ & 0.77 & 1.56 & 1.21 \\
\hline & LC & 0.88 & 0.95 & 1.00 \\
\hline & LW & 0.76 & 0.95 & 0.95 \\
\hline & RW & 1.11 & 1.03 & 1.08 \\
\hline & $\mathrm{MH}$ & 0.95 & 1.08 & 0.80 \\
\hline & MG & 0.81 & 1.00 & 0.75 \\
\hline & AVG & 0.88 & 1.10 & 0.97 \\
\hline & STD & 0.12 & 0.21 & 0.16 \\
\hline
\end{tabular}

Table 10. Ratios of Measured Gamma-Ray Dose Rates.

Free-Field, Phantom Facing the Reactor.

\begin{tabular}{ccccc}
\hline \multicolumn{5}{c}{ RUN NUMBER 131/131 } \\
\hline & \multicolumn{1}{c}{ APRF/ETCA } & APRF/HDL & HDL/ETCA \\
\hline FF DOSE & OUTSIDE & 1.07 & 1.05 & 1.02 \\
& FF BOX & 1.09 & 0.74 & 1.47 \\
\hline \multirow{2}{*}{ DOSE IN PHANTOM } & FB & 1.11 & 1.07 & 1.04 \\
& BB & 1.01 & 0.97 & 1.04 \\
& LC & 1.16 & 1.11 & 1.05 \\
& LW & 1.20 & 1.00 & 1.19 \\
& RW & 1.21 & 1.11 & 1.10 \\
& MH & 1.09 & 1.03 & 1.06 \\
& MG & 1.13 & 1.01 & 1.11 \\
\hline \hline & AVG & 1.13 & 1.04 & 1.08 \\
& STD & 0.06 & 0.05 & 0.05 \\
\hline \hline
\end{tabular}


Table 11. Ratios of Measured Gamma-Ray Dose Rates.

In-Box, Phantom Facing the Reactor.

\begin{tabular}{|c|c|c|c|c|c|c|}
\hline \multicolumn{7}{|c|}{ Run Number 123} \\
\hline & APRF/AFRRI & APRF/ETCA & APRF/'ADL & AFRRI/ETCA & AFRRI/HDL & HDL/ETCA \\
\hline \multicolumn{7}{|c|}{ Free-Field Dose } \\
\hline OUT & 1.20 & 1.07 & 1.05 & 0.89 & 0.87 & 1.02 \\
\hline BOX & 1.13 & 0.89 & 0.92 & 0.79 & 0.82 & 0.97 \\
\hline \multicolumn{7}{|c|}{ Dose rate in Phantom } \\
\hline FB & 1.15 & & 0.83 & & 0.72 & \\
\hline BB & 1.07 & 0.86 & 0.77 & 0.80 & 0.72 & 1.12 \\
\hline LC & 1.24 & 1.03 & 0.83 & 0.83 & 0.67 & 1.24 \\
\hline LW & 1.13 & 0.89 & 0.82 & 0.79 & 0.73 & 1.09 \\
\hline RW & 1.13 & 1.03 & 0.95 & 0.91 & 0.84 & 1.08 \\
\hline $\mathrm{MH}$ & 1.17 & 0.93 & 0.70 & 0.80 & 0.60 & 1.33 \\
\hline MG & 1.19 & 1.09 & 0.79 & 0.91 & 0.66 & 1.39 \\
\hline AVG & 1.15 & 0.97 & 0.81 & 0.84 & 0.71 & 1.21 \\
\hline STD & 0.05 & 0.08 & 0.07 & 0.05 & 0.07 & 0.12 \\
\hline
\end{tabular}


Table 12. Ratios of Measured Gamma-Ray Dose Rates.

In-Box, Phantom Left Side Facing the Reactor.

Run Number 121/122

\begin{tabular}{ccccccc}
\hline & APRF/AFRRI & APRF/ETCA & APRF/HDL & AFRRI/ETCA & AFRRI/HDL & HDL/ETCA \\
\hline OUT & 1.19 & 1.13 & 1.04 & 0.95 & 0.88 & 1.09 \\
BOX & 1.17 & 0.94 & 0.95 & 0.81 & 0.81 & 0.99 \\
\hline \multicolumn{7}{c}{ Free-Field Dose } \\
\hline FB & 1.06 & Dose rates & in Phantom \\
BB & 1.06 & 1.06 & 0.80 & 1.00 & 0.96 & 0.75 \\
LC & 1.12 & 1.09 & 0.97 & 0.97 & 0.87 & 1.33 \\
LW & 1.16 & 1.00 & 0.82 & 0.86 & 0.71 & 1.12 \\
RW & 1.15 & 0.81 & 0.75 & 0.70 & 0.65 & 1.09 \\
MH & 1.21 & 1.00 & 1.02 & 0.83 & 0.85 & 0.98 \\
MG & 1.24 & 1.00 & 0.92 & 0.81 & 0.74 & 1.09 \\
\hline \hline AVG & 1.14 & 0.99 & 0.90 & 0.86 & 0.79 & 1.14 \\
STD & 0.06 & 0.09 & 0.10 & 0.10 & 0.10 & 0.11 \\
\hline \hline
\end{tabular}


Table 13. ORNL Calculations of Neutron Dose Rates in the Free-Field and as a Function of Position on the RT-200 Humanoid Phantom.

Dose rates in $\mathrm{mrad}_{\mathrm{Ti}} / \mathrm{kWh}$.

\begin{tabular}{ccccc}
\hline RUN NUMBER & & 128 & 113 & 120 \\
\hline \hline \multirow{2}{*}{ FF DOSE } & & FF & IN-BOX & IN-BOX \\
& FACING & FACING & LEFT SIDE \\
\hline \multirow{2}{*}{ DOSE IN PHANTOM } & FF BOX & 0.38 & 0.37 & 4.92 \\
& FB & 4.49 & 0.36 & 0.37 \\
\hline & BB & 1.63 & 0.17 & 0.29 \\
& LC & 4.54 & 0.37 & 0.31 \\
& LW & 4.33 & 0.32 & 0.33 \\
& RW & 4.42 & 0.36 & 0.40 \\
& MH & 1.23 & 0.10 & 0.10 \\
& MG & 0.72 & 0.06 & 0.03 \\
\hline \hline
\end{tabular}

Table 14. SAIC Calculations of Neutron Dose Rates in the Free-Field and as a Function of Position on the RT-200 Humanoid Phantom.

Dose rates in $\operatorname{mrad}_{\mathrm{Ti}} / \mathrm{kWh}$.

\begin{tabular}{ccccc}
\hline \hline RUN NUMBER & & 128 & 113 & 120 \\
\hline \hline FF DOSE & OUTSIDE & FF & IN-BOX & IN-BOX \\
& FACING & FACING & LEFT SIDE \\
\hline \multirow{2}{*}{ DOSE IN PHANTOM } & FF BOX & 0.02 & 4.81 & 5.04 \\
& FB & 4.50 & 0.41 & 0.42 \\
\hline & BB & 1.57 & 0.40 & 0.32 \\
& LC & 4.60 & 0.38 & 0.34 \\
& LW & 4.10 & 0.36 & 0.35 \\
& RW & 4.13 & 0.40 & 0.41 \\
& MH & 1.10 & 0.12 & 0.12 \\
& MG & 0.83 & 0.06 & 0.04 \\
\hline \hline
\end{tabular}


Table 15. Ratios of Calculated Neutron Dose Rates. Dose ictes in $\mathrm{mrad}_{T} / \mathrm{kWh}$.

\begin{tabular}{|c|c|c|c|c|}
\hline \multirow[t]{2}{*}{ RUN NUMBER } & & 128 & 113 & 120 \\
\hline & & FF FACING & $\begin{array}{l}\text { IN-BOX } \\
\text { FACING }\end{array}$ & $\begin{array}{l}\text { IN-BOX } \\
\text { LEFT SIDE }\end{array}$ \\
\hline & & ORNL/SAIC & ORNL/SAIC & ORNL/SAIC \\
\hline \multirow[t]{2}{*}{ FF DOSE } & OUTSIDE & 0.99 & 0.98 & 0.98 \\
\hline & FF BOX & 0.67 & 0.90 & 0.88 \\
\hline \multirow[t]{9}{*}{ DOSE IN PHANTOM } & FB & 1.00 & 0.90 & 0.91 \\
\hline & BB & 1.04 & 0.81 & 0.91 \\
\hline & LC & 0.99 & 0.97 & 0.94 \\
\hline & LW & 1.06 & 0.89 & 0.98 \\
\hline & RW: & 1.07 & 0.90 & 1.04 \\
\hline & $\mathrm{MH}$ & 1.12 & 0.83 & 0.83 \\
\hline & Mi:i & 0.87 & 1.00 & 0.75 \\
\hline & $A^{\prime} \cdot G$ & 1.02 & 0.90 & 0.91 \\
\hline & STD & 0.07 & 0.06 & 0.09 \\
\hline
\end{tabular}

Table 16. ORNL Calculations of Ganima-Ray Dose Rates in the Free-Field and as a Function of Position on the RT-200 Humanoid Phantom. Dose rates in $\mathrm{mrad}_{\mathrm{T}} / \mathrm{kWh}$.

\begin{tabular}{ccccc}
\hline RUN NUMBER & & $130 / 131$ & 123 & $121 / 1$ 2 \\
\hline \hline FF DOSE & & FF FACING & $\begin{array}{c}\text { IN-BOX } \\
\text { FACING }\end{array}$ & $\begin{array}{c}\text { IN-BOX } \\
\text { LEFT SIDE }\end{array}$ \\
\hline DUTSIDE & 1.35 & 1.35 & 1.35 \\
& FF BOX & 0.40 & 0.38 & 0.38 \\
\hline DOSE IN PHANTOM & FB & 1.81 & 0.40 & 0.37 \\
& BB & 1.43 & 0.34 & 0.37 \\
& LC & 1.78 & 0.40 & 0.39 \\
& LW & 1.47 & 0.37 & 0.39 \\
& RW & 1.57 & 0.37 & 0.32 \\
& MH & 1.96 & 0.39 & 0.39 \\
& MG & 1.95 & 0.35 & 0.33 \\
\hline \hline
\end{tabular}


Table 17. SAIC Calculations of Gamma-Ray Dose Rates in the Free-Field and as a Function of Position on the RT-200 Humanoid Phantom.

Dose rates in $\mathrm{mrad}_{\mathrm{T}} / \mathrm{kWh}$.

\begin{tabular}{ccccc}
\hline RUN NUMBER & & $130 / 131$ & 123 & $121 / 122$ \\
\hline \hline FF DOSE & & $\begin{array}{c}\text { FF } \\
\text { FACING }\end{array}$ & $\begin{array}{c}\text { IN-BOX } \\
\text { FACING }\end{array}$ & $\begin{array}{c}\text { IN-BOX LEFT } \\
\text { SIDE }\end{array}$ \\
\hline \multirow{2}{*}{ DOSE IN PHANTOM } & OUTSIDE & 1.32 & 1.28 & 1.30 \\
& FF BOX & 0.41 & 0.38 & 0.38 \\
\hline FB & 1.89 & 0.40 & 0.37 \\
& BB & 1.53 & 0.35 & 0.37 \\
& LC & 1.76 & 0.41 & 0.46 \\
& LW & 1.53 & 0.37 & 0.40 \\
& RW & 1.55 & 0.39 & 0.32 \\
& MH & 1.96 & 0.40 & 0.43 \\
& MG & 1.96 & 0.36 & 0.31 \\
\hline \hline
\end{tabular}

Table 18. ORNL Calculations of Gamma-Ray Dose Rates in the Free-Field and as a Function of Position on the RT-200 Humanoid Phantom.

Dose rates in $\mathrm{mrad}_{\mathrm{CaF}} / \mathrm{kWh}$.

\begin{tabular}{ccccc}
\hline RUN NUMBER & & $130 / 131$ & 123 & $121 / 122$ \\
\hline \hline FF DOSE & OUTSIDE & 1.37 & 1.37 & 1.37 \\
& FF BOX & 0.38 & 0.36 & 0.36 \\
\hline \multirow{2}{*}{ DOSE IN PHANTOM } & FB & 1.91 & 0.41 & 0.38 \\
& BB & 1.48 & 0.36 & 0.38 \\
& LC & 1.84 & 0.42 & 0.41 \\
& FEFT SIDE \\
\hline & LW & 1.52 & 0.38 & 0.40 \\
& RW & 1.63 & 0.38 & 0.33 \\
& MH & 2.04 & 0.42 & 0.42 \\
& MG & 2.11 & 0.40 & 0.38 \\
\hline
\end{tabular}


Table 19. SAIC Calculations of Gamma-Ray Dose Rates in the Free-Field and as a Function of Position on the RT-200 Humanoid Phantom.

Dose rates in $\mathrm{mrad}_{\mathrm{CaF}} / \mathrm{kWh}$.

\begin{tabular}{ccccc}
\hline RUN NUMBER & & $130 / 131$ & 123 & $121 / 122$ \\
\hline \hline FF DOSE & & $\begin{array}{c}\text { FF } \\
\text { FACING }\end{array}$ & $\begin{array}{c}\text { IN-BOX } \\
\text { FACING }\end{array}$ & $\begin{array}{c}\text { IN-BOX LEFT } \\
\text { SIDE }\end{array}$ \\
\hline \multirow{2}{*}{ DOSE IN PHANTOM } & OUTSIDE & 1.46 & 1.43 & 1.44 \\
& FF BOX & 0.42 & 0.38 & 0.39 \\
\hline & FB & 2.11 & 0.43 & 0.40 \\
& BB & 1.76 & 0.38 & 0.40 \\
& LC & 1.98 & 0.45 & 0.49 \\
& LW & 1.71 & 0.39 & 0.42 \\
& RW & 1.74 & 0.41 & 0.36 \\
& MH & 2.22 & 0.43 & 0.47 \\
& MG & 2.32 & 0.44 & 0.37 \\
\hline \hline
\end{tabular}

Table 20. Ratios of Calculated Gamma-Ray Dose Rates.

Dose rates in $\mathrm{mrad}_{\mathrm{T}} / \mathrm{kWh}$.

\begin{tabular}{ccccc}
\hline RUN NUMBER & & $130 / 131$ & 123 & $121 / 122$ \\
\hline \hline & & FF FACING & $\begin{array}{c}\text { IN-BOX } \\
\text { FACING }\end{array}$ & $\begin{array}{c}\text { IN-BOX } \\
\text { LEFT SIDE }\end{array}$ \\
\hline \hline FF DOSE & OUTSIDE & ORNL/SAIC & ORNL/SAIC & ORNL/SAIC \\
& FF BOX & 0.98 & 1.05 & 1.04 \\
& FB & 0.96 & 1.00 & 1.00 \\
\hline DOSE IN PHANTOM & BB & 0.93 & 0.97 & 1.00 \\
& LC & 1.01 & 0.98 & 1.00 \\
& LW & 0.96 & 1.00 & 0.85 \\
& RW & 1.01 & 0.95 & 1.00 \\
& MH & 1.00 & 0.98 & 0.91 \\
& MG & 0.99 & 0.97 & 1.06 \\
\hline \hline & AVG & 0.98 & 0.98 & 0.97 \\
& STD & 0.03 & 0.02 & 0.07 \\
\hline \hline
\end{tabular}


Table 21. Ratios of the Calculated Gamma-Ray Dose Rates. Dose rates in $\mathrm{mrad}_{\mathrm{Caf}} / \mathrm{kWh}$.

\begin{tabular}{|c|c|c|c|c|}
\hline RUN NUMBER & & $130 / 131$ & 123 & $121 / 122$ \\
\hline & & FF FACING & $\begin{array}{l}\text { IN-BOX } \\
\text { FACING }\end{array}$ & $\begin{array}{c}\text { IN-BOX } \\
\text { LEFT SIDE }\end{array}$ \\
\hline & & ORNL/SAIC & ORNL/SAIC & ORNL/SAIC \\
\hline \multirow[t]{2}{*}{ FF DOSE } & OUTSIDE & 0.94 & 0.96 & 0.95 \\
\hline & FF BOX & 0.90 & 0.96 & 0.92 \\
\hline \multirow[t]{9}{*}{ DOSE IN PHANTOM } & FB & 0.91 & 0.95 & 0.95 \\
\hline & $\mathrm{BB}$ & 0.84 & 0.95 & 0.95 \\
\hline & LC & 0.93 & 0.93 & 0.84 \\
\hline & LW & 0.89 & 0.97 & 0.95 \\
\hline & RW & 0.94 & 0.93 & 0.92 \\
\hline & MH & 0.92 & 0.98 & 0.89 \\
\hline & MG & 0.91 & 0.91 & 1.03 \\
\hline & AVG & 0.90 & 0.95 & 0.93 \\
\hline & STD & 0.03 & 0.02 & 0.05 \\
\hline
\end{tabular}


Table 22. Measured and Calculated Neutron Dose Rates and Reduction Factors.

Free-Field, Phantom Facing the Reactor.

Comparisons with APRF Measurements.

Dose rates in $\operatorname{mrad}_{\mathrm{T}} \mathrm{kWh}$.

\begin{tabular}{|c|c|c|c|c|c|c|c|c|c|c|}
\hline \multicolumn{11}{|c|}{ Run Number 128} \\
\hline & DOSE & OR & $\mathrm{C} / \mathrm{M}$ & SAI & $\mathrm{C} / \mathrm{M}$ & RF & OR & $\mathrm{C} / \mathrm{M}$ & SAI & $\mathrm{C} / \mathrm{M}$ \\
\hline \multicolumn{11}{|c|}{ Free-Field Dose } \\
\hline OUT & 4.26 & 4.97 & 1.17 & 5.02 & 1.18 & & & & & \\
\hline BOX & & 0.38 & & 0.57 & & & 13.08 & & 8.81 & \\
\hline \multicolumn{11}{|c|}{ Dose rate in Phantom } \\
\hline FB & & 4.49 & & 4.50 & & & 1.11 & & 1.12 & \\
\hline BB & 1.20 & 1.63 & 1.36 & 1.57 & 1.31 & 3.55 & 3.05 & 0.86 & 3.20 & 0.90 \\
\hline LC & 3.72 & 4.54 & 1.22 & 4.60 & 1.24 & 1.15 & 1.09 & 0.95 & 1.09 & 0.95 \\
\hline LW & 3.60 & 4.33 & 1.20 & 4.10 & 1.14 & 1.18 & 1.15 & 0.97 & 1.22 & 1.04 \\
\hline RW & 3.91 & 4.42 & 1.13 & 4.13 & 1.06 & 1.09 & 1.12 & 1.03 & 1.22 & 1.12 \\
\hline $\mathrm{MH}$ & 1.16 & 1.23 & 1.06 & 1.10 & 0.95 & 3.67 & 4.04 & 1.10 & 4.56 & 1.24 \\
\hline MG & 0.65 & 0.72 & 1.11 & 0.83 & 1.28 & 6.55 & 6.90 & 1.05 & 6.05 & 0.92 \\
\hline AVG & 2.37 & 3.05 & 1.18 & 2.98 & 1.16 & 2.87 & 2.64 & 0.99 & 2.64 & 1.03 \\
\hline STD & 1.38 & 1.63 & 0.10 & 1.59 & 0.13 & 1.98 & 2.05 & 0.08 & 1.87 & 0.12 \\
\hline
\end{tabular}


Table 23. Measured and Calculated Neutron Dose Rates and Reduction Factors.

In-Box, Phantom Facing the Reactor.

Comparisons with APRF Measurements.

Dose rates in $\operatorname{mrad}_{\mathrm{T}} / \mathrm{kWh}$.

\begin{tabular}{ccccccccccc}
\hline \multicolumn{10}{c}{ Run Number 113 } \\
\hline & DOSE & OR & C/M & SAI & C/M & RF & OR & C/M & SAI & C/M \\
\hline OUT & 3.88 & 4.69 & 1.21 & 4.81 & 1.24 & \\
BOX & 0.37 & 0.37 & 1.00 & 0.41 & 1.11 & 10.49 & 12.68 & 1.21 & 11.73 & 1.12 \\
\hline & & & \multicolumn{10}{c}{ Free-Field Dose } \\
\hline FB & & 0.36 & & 0.40 & & & & \\
BB & 0.25 & 0.17 & 0.68 & 0.21 & 0.84 & 15.52 & 27.59 & 1.78 & 22.90 & 1.48 \\
LC & 0.37 & 0.37 & 1.00 & 0.38 & 1.03 & 10.49 & 12.68 & 1.21 & 12.66 & 1.21 \\
LW & 0.35 & 0.32 & 0.91 & 0.36 & 1.03 & 11.09 & 14.66 & 1.32 & 13.36 & 1.20 \\
RW & 0.38 & 0.36 & 0.95 & 0.40 & 1.05 & 10.21 & 13.03 & 1.28 & 12.03 & 1.18 \\
MH & 0.13 & 0.10 & 0.77 & 0.12 & 0.92 & 29.85 & 46.90 & 1.57 & 40.08 & 1.34 \\
MG & 0.06 & 0.06 & 1.00 & 0.06 & 1.00 & 64.67 & 78.17 & 1.21 & 80.17 & 1.24 \\
\hline \hline AVG & 0.26 & 0.25 & 0.89 & 0.28 & 0.98 & 23.64 & 29.44 & 1.39 & 27.60 & 1.27 \\
STD & 0.12 & 0.12 & 0.12 & 0.13 & 0.07 & 19.57 & 23.06 & 0.21 & 23.46 & 0.10 \\
\hline \hline
\end{tabular}


Table 24. Measured and Calculated Neutron Dose Rates and Reduction Factors.

In-Box, Phantom Left Side Facing the Reactor.

Comparisons with APRF Measurements.

Dose rates in $\operatorname{mrad}_{\mathrm{T}} / \mathrm{kWh}$.

\begin{tabular}{|c|c|c|c|c|c|c|c|c|c|c|}
\hline \multicolumn{11}{|c|}{ Run Number 120} \\
\hline & DOSE & OR & $\mathrm{C} / \mathrm{M}$ & SAI & $\mathrm{C} / \mathrm{M}$ & RF & OR & $\mathrm{C} / \mathrm{M}$ & SAI & $\mathrm{C} / \mathrm{M}$ \\
\hline \multicolumn{11}{|c|}{ Free-Field Dose } \\
\hline OUT & 3.88 & 4.92 & 1.27 & 5.04 & 1.30 & & & & & \\
\hline BOX & 0.36 & 0.37 & 0.86 & 0.42 & 1.17 & 10.78 & 13.30 & 1.23 & 12.00 & 1.11 \\
\hline \multicolumn{11}{|c|}{ Dose rate in Phantom } \\
\hline FB & & 0.29 & & 0.32 & & & 16.97 & & & \\
\hline BB & 0.35 & 0.31 & 0.89 & 0.34 & 0.97 & 11.09 & 15.87 & 1.43 & 14.82 & 1.34 \\
\hline LC & 0.32 & 0.33 & 1.03 & 0.35 & 1.09 & 12.13 & 14.91 & 1.23 & 14.40 & 1.19 \\
\hline LW & 0.36 & 0.40 & 1.11 & 0.41 & 1.14 & 10.78 & 12.30 & 1.14 & 12.29 & 1.14 \\
\hline RW & 0.27 & 0.26 & 0.96 & 0.25 & 0.93 & 14.37 & 18.92 & 1.32 & 20.16 & 1.40 \\
\hline MH & 0.12 & 0.10 & 0.83 & 0.12 & 1.00 & 32.33 & 49.20 & 1.52 & 42.00 & 1.30 \\
\hline MG & 0.03 & 0.03 & 1.00 & 0.04 & 1.33 & 129.33 & 164.00 & 1.27 & 126.00 & 0.97 \\
\hline AVG & 0.24 & 0.25 & 0.97 & 0.26 & 1.08 & 35.01 & 41.74 & 1.32 & 38.28 & 1.22 \\
\hline STD & 0.12 & 0.12 & 0.09 & 0.12 & 0.14 & 42.84 & 51.26 & 0.13 & 40.48 & 0.14 \\
\hline
\end{tabular}


Table 25. Measured and Calculated Neutron Dose Rates and Reduction Factors.

Free-Field, Phantom Facing the Reactor.

Comprarisons with ETCA Measurements.

Dose rates in $\operatorname{mrad}_{\mathrm{T}} / \mathrm{kWh}$.

\begin{tabular}{|c|c|c|c|c|c|c|c|c|c|c|}
\hline \multicolumn{11}{|c|}{ Run Number 128} \\
\hline & DOSE & OR & $\mathrm{C} / \mathrm{M}$ & SAI & $\mathrm{C} / \mathrm{M}$ & RF & OR & $\mathrm{C} / \mathbb{M}$ & SAI & $\mathrm{C} / \mathrm{M}$ \\
\hline \multicolumn{11}{|c|}{ Free-Field Dose } \\
\hline OUT & 4.78 & 4.97 & 1.04 & 5.02 & 1.05 & & & & & \\
\hline $\mathrm{BOX}$ & 0.37 & 0.38 & 1.03 & 0.57 & 1.54 & 12.92 & 13.08 & 1.01 & 8.81 & 0.68 \\
\hline \multicolumn{11}{|c|}{ Dose rate in Phantom } \\
\hline $\mathrm{FB}$ & 4.46 & 4.49 & 1.01 & 4.50 & 1.01 & 1.07 & 1.11 & 1.04 & 1.12 & 1.04 \\
\hline $\mathrm{BB}$ & 1.55 & 1.63 & 1.05 & 1.57 & 1.01 & 3.08 & 3.05 & 0.99 & 3.20 & 1.04 \\
\hline LC & 4.24 & 4.54 & 1.07 & 4.60 & 1.08 & 1.13 & 1.09 & 0.96 & 1.09 & 0.97 \\
\hline LW & 4.74 & 4.33 & 0.91 & 4.10 & 0.86 & 1.01 & 1.15 & 1.14 & 1.22 & 1.21 \\
\hline RW & 3.52 & 4.42 & 1.26 & 4.13 & 1.17 & 1.36 & 1.12 & 0.82 & 1.22 & 0.89 \\
\hline MH & 1.22 & 1.23 & 1.01 & 1.10 & 0.90 & 3.92 & 4.04 & 1.03 & 4.56 & 1.16 \\
\hline MG & 0.80 & 0.72 & 0.90 & 0.83 & 1.04 & 5.98 & 6.90 & 1.15 & 6.05 & 1.01 \\
\hline AVG & 2.93 & 3.05 & 1.03 & 2.98 & 1.01 & 2.51 & 2.64 & 1.02 & 2.64 & 1.05 \\
\hline STD & 1.56 & 1.63 & 0.11 & 1.59 & 0.10 & 1.77 & 2.05 & 0.10 & 1.87 & 0.10 \\
\hline
\end{tabular}


Table 26. Measured and Calculated Neutron Dose Rates and Reduction Factors.

In-Box, Phantom Facing the Reactor.

Comparisons with ETCA Measurements.

Dose rates in $\mathrm{mrad}_{\mathrm{T}} / \mathrm{kWh}$.

\begin{tabular}{ccccccccccc}
\hline \multicolumn{10}{c}{} & \multicolumn{10}{c}{ Run Number 123 } \\
\hline & DOSE & OR & C/M & SAI & C/M & RF & OR & C/M & SAI & C/M \\
\hline OUT & 3.51 & 4.69 & 1.34 & 4.81 & 1.37 & & \\
BOX & 0.41 & 0.37 & 0.73 & 0.41 & 1.00 & 8.56 & 12.68 & 1.48 & 11.73 & 1.37 \\
\hline & & & \multicolumn{10}{c}{ Dree-Field Dose } \\
\hline FB & & 0.36 & & 0.40 & & & & \\
BB & 0.16 & 0.17 & 1.06 & 0.21 & 1.31 & 21.94 & 27.59 & 1.26 & 22.90 & 1.04 \\
LC & 0.39 & 0.37 & 0.95 & 0.38 & 0.97 & 9.00 & 12.68 & 1.41 & 12.66 & 1.41 \\
LW & 0.37 & 0.32 & 0.86 & 0.36 & 0.97 & 9.49 & 14.66 & 1.54 & 13.36 & 1.41 \\
RW & 0.37 & 0.36 & 0.97 & 0.40 & 1.08 & 9.49 & 13.03 & 1.37 & 12.03 & 1.27 \\
MH & 0.12 & 0.10 & 0.83 & 0.12 & 1.00 & 29.25 & 46.90 & 1.60 & 40.08 & 1.37 \\
MG & 0.06 & 0.06 & 1.00 & 0.06 & 1.00 & 58.80 & 78.17 & 1.33 & 80.17 & 1.36 \\
\hline \hline AVG & 0.25 & 0.25 & 0.95 & 0.28 & 1.06 & 23.00 & 29.44 & 1.42 & 27.60 & 1.31 \\
STD & 0.14 & 0.12 & 0.08 & 0.13 & 0.12 & 17.71 & 23.06 & 0.12 & 23.46 & 0.13 \\
\hline \hline
\end{tabular}


Table 27. Measured and Calculated Neutron Dose Rates and Reduction Factors.

In-Box, Phantom Left Side Facing the Reactor.

Comparisons with ETCA Measurements.

Dose rates in $\operatorname{mrad}_{T} / \mathrm{kWh}$.

\begin{tabular}{|c|c|c|c|c|c|c|c|c|c|c|}
\hline \multicolumn{11}{|c|}{ Run Number 120} \\
\hline & DOSE & OR & $\mathrm{C} / \mathrm{M}$ & SAI & $\mathrm{C} / \mathrm{M}$ & $\mathrm{RF}$ & OR & $\mathrm{C} / \mathrm{M}$ & SAI & $\mathrm{C} / \mathrm{M}$ \\
\hline \multicolumn{11}{|c|}{ Free-Field Dose } \\
\hline OUT & 4.15 & 4.92 & 1.19 & 5.04 & 1.21 & & & & & \\
\hline BOX & 0.33 & 0.37 & 1.12 & 0.42 & 1.27 & 12.58 & 13.30 & 1.06 & 12.00 & 0.95 \\
\hline \multicolumn{11}{|c|}{ Dose ra.e in Phantom } \\
\hline FB & & 0.29 & & 0.32 & & & 16.97 & & & \\
\hline BB & 0.29 & 0.31 & 1.07 & 0.34 & 1.17 & 14.31 & 15.87 & 1.11 & 14.82 & 1.04 \\
\hline LC & 0.32 & 0.33 & 1.03 & 0.35 & 1.09 & 12.97 & 14.91 & 1.15 & 14.40 & 1.11 \\
\hline LW & 0.38 & 0.40 & 1.05 & 0.41 & 1.08 & 10.92 & 12.30 & 1.13 & 12.29 & 1.13 \\
\hline RW & 0.25 & 0.26 & 1.04 & 0.25 & 1.00 & 16.60 & 18.92 & 1.14 & 20.16 & 1.21 \\
\hline MH & 0.15 & 0.10 & 0.67 & 0.12 & 0.80 & 27.67 & 49.20 & 1.78 & 42.00 & 1.52 \\
\hline MG & 0.04 & 0.03 & 0.75 & 0.04 & 1.00 & 103.75 & 164.00 & 1.58 & 126.00 & 1.21 \\
\hline AVG & 0.24 & 0.25 & 0.94 & 0.26 & 1.02 & 31.04 & 41.74 & 1.31 & 38.28 & 1.20 \\
\hline STD & 0.11 & 0.12 & 0.16 & 0.12 & 0.12 & 32.96 & 51.26 & 0.26 & 40.48 & 0.15 \\
\hline
\end{tabular}


Table 28. Measured and Calculated Gamma-Ray Dose Rates and Reduction Factors.

Free-Field, Phantom Facing the Reactor.

Comparisons with APRF Measurements.

Dose rates in $\mathrm{mrad}_{\mathrm{T}} / \mathrm{kWh}$.

\begin{tabular}{ccccccccccc}
\hline \multicolumn{10}{c}{} & \multicolumn{10}{c}{ Run Number 130/131 } \\
\hline & DOSE & OR & C/M & SAI & C/M & RF & OR & C/M & SAI & C/M \\
\hline OUT & 1.49 & 1.35 & 0.91 & 1.32 & 0.89 \\
BOX & 0.35 & 0.40 & 1.06 & 0.41 & 1.17 & 4.26 & 3.38 & 0.79 & 3.22 & 0.76 \\
\hline & & & \multicolumn{10}{c}{ Free-Field Dose } \\
\hline FB & 2.02 & 1.81 & 0.90 & 1.89 & 0.94 & 0.74 & 0.75 & 1.01 & 0.70 & 0.94 \\
BB & 1.45 & 1.43 & 0.99 & 1.53 & 1.06 & 1.03 & 0.94 & 0.91 & 0.86 & 0.84 \\
LC & 2.05 & 1.78 & 0.87 & 1.76 & 0.86 & 0.73 & 0.76 & 1.04 & 0.75 & 1.03 \\
LW & 1.82 & 1.47 & 0.81 & 1.53 & 0.84 & 0.82 & 0.92 & 1.12 & 0.86 & 1.05 \\
RW & 1.82 & 1.57 & 0.86 & 1.55 & 0.85 & 0.82 & 0.86 & 1.05 & 0.85 & 1.04 \\
MH & 2.03 & 1.96 & 0.97 & 1.96 & 0.97 & 0.73 & 0.69 & 0.95 & 0.67 & 0.92 \\
MG & 2.04 & 1.95 & 0.96 & 1.96 & 0.96 & 0.73 & 0.69 & 0.95 & 0.67 & 0.92 \\
\hline \hline AVG & 1.89 & 1.71 & 0.91 & 1.74 & 0.92 & 0.80 & 0.80 & 1.00 & 0.77 & 0.96 \\
STD & 0.20 & 0.20 & 0.06 & 0.19 & 0.07 & 0.10 & 0.10 & 0.07 & 0.08 & 0.07 \\
\hline \hline
\end{tabular}


Table 29. Measured and Calculated Gamma-Ray Dose Rates and Reduction Factors.

In-Box, Phantom Facing the Reactor.

Comparisons with APRF Measurements.

Dose rates in $\operatorname{mrad}_{\mathrm{T}} / \mathrm{kWh}$.

\begin{tabular}{|c|c|c|c|c|c|c|c|c|c|c|}
\hline \multicolumn{11}{|c|}{ Run Nrmber 123} \\
\hline & DOSE & OR & $\mathrm{C} / \mathrm{M}$ & SAI & $\mathrm{C} / \mathrm{M}$ & $\mathrm{RF}$ & OR & $\mathrm{C} / \mathrm{M}$ & SAI & $\mathrm{C} / \mathrm{M}$ \\
\hline \multicolumn{11}{|c|}{ Free-Field Dose } \\
\hline OUT & 1.48 & 1.35 & 0.91 & 1.28 & 0.86 & & & & & \\
\hline $\mathrm{BCX}$ & 0.34 & 0.38 & 1.12 & 0.38 & 1.12 & 4.35 & 3.55 & 0.82 & 3.37 & 0.77 \\
\hline \multicolumn{11}{|c|}{ Dose in Phantom } \\
\hline FB & 0.38 & 0.40 & 1.05 & 0.40 & 1.05 & 3.89 & 3.38 & 0.87 & 3.20 & 0.82 \\
\hline BB & 0.30 & 0.34 & 1.13 & 0.35 & 1.17 & 4.93 & 3.97 & 0.81 & 3.66 & 0.74 \\
\hline LC & 0.41 & 0.40 & 0.98 & 0.41 & 1.00 & 3.61 & 3.38 & 0.94 & 3.12 & 0.86 \\
\hline LW & 0.34 & 0.37 & 1.09 & 0.37 & 1.09 & 4.35 & 3.65 & 0.84 & 3.46 & 0.80 \\
\hline RW & 0.35 & 0.37 & 1.06 & 0.39 & 1.11 & 4.23 & 3.65 & 0.86 & 3.28 & 0.78 \\
\hline $\mathrm{MH}$ & 0.41 & 0.39 & 0.95 & 0.40 & 0.98 & 3.61 & 3.46 & 0.96 & 3.20 & 0.89 \\
\hline MG & 0.37 & 0.35 & 0.95 & 0.36 & 0.97 & 4.00 & 3.86 & 0.97 & 3.56 & 0.89 \\
\hline AVG & 0.37 & 0.37 & 1.03 & 0.38 & 1.05 & 4.09 & 3.62 & 0.89 & 3.35 & 0.83 \\
\hline STD & 0.04 & 0.02 & 0.07 & 0.02 & 0.07 & 0.43 & 0.21 & 0.06 & 0.19 & 0.05 \\
\hline
\end{tabular}


Table 30. Measured and Calculated Gamma-Ray Dose Rates and Reduction Factors.

In-Box, Phantom Left Side Facing the Reactor.

Comparisons with APRF Measurements.

Dose rates in $\operatorname{mrad}_{T} / \mathrm{kWh}$.

\begin{tabular}{|c|c|c|c|c|c|c|c|c|c|c|}
\hline \multicolumn{11}{|c|}{ Run Number $121 / 122$} \\
\hline & DOSE & OR & $\mathrm{C} / \mathrm{M}$ & SAI & $\mathrm{C} / \mathrm{M}$ & RF & OR & $\mathrm{C} / \mathrm{M}$ & SAI & $\mathrm{C} / \mathrm{M}$ \\
\hline \multicolumn{11}{|c|}{ Free-Field Dose } \\
\hline OUT & 1.47 & 1.35 & 0.92 & 1.30 & 0.88 & & & & & \\
\hline BOX & 0.34 & 0.38 & 1.12 & 0.38 & 1.12 & 4.32 & 3.55 & 0.82 & 3.42 & 0.79 \\
\hline \multicolumn{11}{|c|}{ Dose in Phantom } \\
\hline FB & 0.35 & 0.37 & 1.06 & 0.37 & 1.06 & 4.20 & 3.65 & 0.87 & 3.51 & 0.84 \\
\hline BB & 0.34 & 0.37 & 1.09 & 0.37 & 1.09 & 4.32 & 3.65 & 0.84 & 3.51 & 0.81 \\
\hline LC & 0.38 & 0.39 & 1.03 & 0.46 & 1.21 & 3.87 & 3.46 & 0.89 & 2.83 & 0.73 \\
\hline LW & 0.36 & 0.39 & 1.08 & 0.40 & 1.11 & 4.08 & 3.46 & 0.85 & 3.25 & 0.80 \\
\hline RW & 0.30 & 0.32 & 1.07 & 0.32 & 1.07 & 4.90 & 4.22 & 0.86 & 4.06 & 0.83 \\
\hline MH & 0.41 & 0.39 & 0.95 & 0.43 & 1.05 & 3.59 & 3.46 & 0.96 & 3.02 & 0.84 \\
\hline MG & 0.36 & 0.33 & 0.92 & 0.31 & 0.86 & 4.08 & 4.09 & 1.00 & 4.19 & 1.03 \\
\hline AVG & 0.36 & 0.37 & 1.03 & 0.38 & 1.06 & 4.15 & 3.71 & 0.90 & 3.48 & 0.84 \\
\hline STD & 0.03 & 0.03 & 0.06 & 0.05 & 0.10 & 0.38 & 0.29 & 0.06 & 0.47 & 0.08 \\
\hline
\end{tabular}


Table 31. Measured and Calculated Gamma-Ray Dose Rates and Reduction Factors.

In-Box, Phantom Facing the Reactor.

Comparisons with AFRRI Measurements.

Dose rates in $\mathrm{mrad}_{\mathrm{T}} / \mathrm{kWh}$.

\begin{tabular}{ccccccccccc}
\hline \hline \multicolumn{10}{c}{ Run Number 123 } \\
\hline & DOSE & OR & C/M & SAI & C/M & RF & OR & C/M & SAI & C/M \\
\hline OUT & 1.23 & 1.35 & 1.10 & 1.28 & 1.04 \\
BOX & 0.30 & 0.38 & 1.27 & 0.38 & 1.27 & 4.10 & 3.55 & 0.87 & 3.37 & 0.82 \\
\hline & & & \multicolumn{10}{c}{ Free-Field Dose } \\
\hline FB & 0.33 & 0.40 & 1.21 & 0.40 & 1.21 & 3.73 & 3.38 & 0.91 & 3.20 & 0.86 \\
BB & 0.28 & 0.34 & 1.21 & 0.35 & 1.25 & 4.39 & 3.97 & 0.90 & 3.66 & 0.83 \\
LC & 0.33 & 0.40 & 1.21 & 0.41 & 1.24 & 3.73 & 3.38 & 0.91 & 3.12 & 0.84 \\
LW & 0.30 & 0.37 & 1.23 & 0.37 & 1.23 & 4.10 & 3.65 & 0.89 & 3.46 & 0.84 \\
RW & 0.31 & 0.37 & 1.19 & 0.39 & 1.26 & 3.97 & 3.65 & 0.92 & 3.28 & 0.83 \\
MH & 0.35 & 0.39 & 1.11 & 0.40 & 1.14 & 3.51 & 3.46 & 0.99 & 3.20 & 0.91 \\
MG & 0.31 & 0.35 & 1.13 & 0.36 & 1.16 & 3.97 & 3.86 & 0.97 & 3.56 & 0.90 \\
\hline \hline AVG & 0.32 & 0.37 & 1.19 & 0.38 & 1.21 & 3.91 & 3.62 & 0.93 & 3.35 & 0.86 \\
STD & 0.02 & 0.02 & 0.04 & 0.02 & 0.04 & 0.27 & 0.21 & 0.03 & 0.19 & 0.03 \\
\hline \hline
\end{tabular}


Table 32. Measured and Calculated Gamma-Ray Dose Rates and Reduction Factors.

In-Box, Phantom Left Side Facing the Reactor.

romparisons with AFRRI Measurements.

Dose rates in $\operatorname{mrad}_{T} / \mathrm{kWh}$.

\begin{tabular}{|c|c|c|c|c|c|c|c|c|c|c|}
\hline \multicolumn{11}{|c|}{ Run Number $121 / 122$} \\
\hline & DOSE & OR & $\mathrm{C} / \mathrm{M}$ & SAI & $\mathrm{C} / \mathrm{M}$ & RF & OR & $\mathrm{C} / \mathrm{M}$ & SAI & $\mathrm{C} / \mathrm{M}$ \\
\hline \multicolumn{11}{|c|}{ Free-Field Dose } \\
\hline OUT & 1.24 & 1.35 & 1.09 & 1.30 & 1.05 & & & & & \\
\hline BOX & 0.29 & 0.38 & 1.31 & 0.38 & 1.31 & 4.28 & 3.55 & 0.83 & 3.42 & 0.80 \\
\hline \multicolumn{11}{|c|}{ Dose in Phantom } \\
\hline FB & 0.33 & 0.37 & 1.12 & 0.37 & 1.12 & 3.75 & 3.65 & 0.97 & 3.51 & 0.93 \\
\hline BB & 0.32 & 0.37 & 1.16 & 0.37 & 1.16 & 3.88 & 3.65 & 0.94 & 3.51 & 0.91 \\
\hline LC & 0.34 & 0.39 & 1.15 & 0.46 & 1.35 & 3.64 & 3.46 & 0.95 & 2.83 & 0.78 \\
\hline LW & 0.31 & 0.39 & 1.26 & 0.40 & 1.29 & 4.00 & $2: 0$ & 0.87 & 3.25 & 0.81 \\
\hline RW & 0.26 & 0.32 & 1.23 & 0.32 & 1.23 & 4.77 & 4.22 & 0.88 & 4.06 & 0.85 \\
\hline MH & 0.34 & 0.39 & 1.15 & 0.43 & 1.26 & 3.65 & 3.46 & 0.95 & 3.02 & 0.83 \\
\hline MG & 0.29 & 0.33 & 1.14 & 0.31 & 1.07 & 4.28 & 459 & 0.96 & 4.19 & 0.98 \\
\hline$A V G$ & 0.31 & 0.37 & 1.17 & 0.38 & 1.21 & 4.00 & 3.71 & 0.93 & 3.48 & 0.87 \\
\hline STD & 0.03 & 0.03 & 0.05 & 0.05 & 0.09 & 0.38 & 0.29 & $0 . .4$ & 0.47 & 0.07 \\
\hline
\end{tabular}


Table 33. Measured and Calculated Gamma-Ray Doses Rates and Reduction Factors.

Free-Field, Phantom Facing the Reactor.

Comparisons with HDL Measurements.

Dose rates in $\mathrm{mrad}_{\mathrm{CaF}} / \mathrm{kWh}$.

\begin{tabular}{ccccccccccc}
\hline \multicolumn{10}{c}{} & \multicolumn{10}{c}{ Run Number 130/131 } \\
\hline & DOSE & OR & C/M & SAI & C/M & RF & OR & C/M & SAI & C/M \\
\hline OUT & 1.23 & 1.37 & 1.11 & 1.46 & 1.19 \\
BOX & 0.41 & 0.38 & 0.93 & 0.42 & 1.02 & 3.00 & 3.61 & 1.20 & 3.45 & 1.15 \\
\hline & & & \multicolumn{7}{c}{ Free-Field Dose } \\
\hline FB & 1.65 & 1.91 & 1.16 & 2.11 & 1.28 & 0.75 & 0.72 & 0.96 & 0.69 & 0.92 \\
BB & 1.30 & 1.48 & 1.14 & 1.76 & 1.35 & 0.95 & 0.93 & 0.98 & 0.83 & 0.87 \\
LC & 1.61 & 1.84 & 1.14 & 1.98 & 1.23 & 0.76 & 0.74 & 0.97 & 0.74 & 0.97 \\
LW & 1.58 & 1.52 & 0.96 & 1.71 & 1.08 & 0.78 & 0.90 & 1.15 & 0.85 & 1.09 \\
RW & 1.43 & 1.63 & 1.14 & 1.74 & 1.22 & 0.86 & 0.84 & 0.98 & 0.84 & 0.98 \\
MH & 1.72 & 2.04 & 1.19 & 2.22 & 1.29 & 0.72 & 0.67 & 0.93 & 0.66 & 0.92 \\
MG & 1.75 & 2.11 & 1.21 & 2.32 & 1.33 & 0.70 & 0.65 & 0.93 & 0.63 & 0.90 \\
\hline AVG & 1.58 & 1.79 & 1.13 & 1.98 & 1.25 & 0.79 & 0.78 & 0.99 & 0.75 & 0.95 \\
STD & 0.15 & 0.23 & 0.07 & 0.23 & 0.08 & 0.08 & 0.10 & 0.07 & 0.09 & 0.07 \\
\hline \hline
\end{tabular}


Table 34. Measured and Calculated Gamma-Ray Dose Rates and Reduction Factors.

In-Box, Phantom Facing the Reactor.

Comparisons with HDL Measurements.

Dose rates in $\mathrm{mrad}_{\mathrm{CaF}} / \mathrm{kWh}$.

\begin{tabular}{ccccccccccc}
\hline \multicolumn{10}{c}{} & \multicolumn{10}{c}{ Run Number 123 } \\
\hline & DOSE & OR & C/M & SAI & C/M & RF & OR & C/M & SAI & C/M \\
\hline OUT & 1.23 & 1.37 & 1.11 & 1.43 & 1.16 \\
BOX & 0.32 & 0.36 & 1.13 & 0.38 & 1.19 & 3.84 & 3.81 & 0.99 & 3.76 & 0.98 \\
\hline & & & \multicolumn{7}{c}{ Dree-Field Dose } \\
\hline FB & 0.40 & 0.41 & 1.03 & 0.43 & 1.08 & 3.08 & 3.34 & 1.08 & 3.33 & 1.08 \\
BB & 0.34 & 0.36 & 1.06 & 0.38 & 1.12 & 3.62 & 3.81 & 1.05 & 3.76 & 1.04 \\
LC & 0.43 & 0.42 & 0.98 & 0.45 & 1.05 & 2.86 & 3.26 & 1.14 & 3.18 & 1.11 \\
LW & 0.36 & 0.38 & 1.06 & 0.39 & 1.08 & 3.42 & 3.61 & 1.06 & 3.67 & 1.07 \\
RW & 0.32 & 0.38 & 1.19 & 0.41 & 1.28 & 3.84 & 3.61 & 0.94 & 3.49 & 0.91 \\
MH & 0.51 & 0.42 & 0.82 & 0.43 & 0.84 & 2.41 & 3.26 & 1.35 & 3.33 & 1.38 \\
MG & 0.41 & 0.40 & 0.98 & 0.44 & 1.07 & 3.00 & 3.43 & 1.14 & 3.25 & 1.08 \\
\hline \hline AVG & 0.40 & 0.40 & 1.01 & 0.42 & 1.07 & 3.18 & 3.47 & 1.11 & 3.43 & 1.10 \\
STD & 0.06 & 0.02 & 0.10 & 0.02 & 0.12 & 0.45 & 0.19 & 0.12 & 0.20 & 0.13 \\
\hline \hline
\end{tabular}


Table 35. Measured and Calculated Gamma-Ray Dose Rates and Reduction Factors.

In-Box, Phantom Left Side Facing the Reactor.

Comparisons with HDL Measurements.

Dose rates in $\mathrm{mrad}_{\mathrm{CaF}} / \mathrm{kWh}$.

\begin{tabular}{|c|c|c|c|c|c|c|c|c|c|c|}
\hline \multicolumn{11}{|c|}{ Run Number $121 / 122$} \\
\hline & DOSE & OR & $\mathrm{C} / \mathrm{M}$ & SAI & $\mathrm{C} / \mathrm{M}$ & RF & OR & $\mathrm{C} / \mathrm{M}$ & SAI & $\mathrm{C} / \mathrm{M}$ \\
\hline \multicolumn{11}{|c|}{ Free-Field Dose } \\
\hline OUT & 1.23 & 1.37 & 1.11 & 1.44 & 1.17 & & & & & \\
\hline BOX & 0.31 & 0.36 & 1.16 & 0.39 & 1.26 & 3.97 & 3.81 & 0.96 & 3.69 & 0.93 \\
\hline \multicolumn{11}{|c|}{ Dose in Phantom } \\
\hline FB & 0.30 & 0.38 & 1.27 & 0.40 & 1.33 & 4.10 & 3.61 & 0.88 & 3.60 & 0.88 \\
\hline BB & 0.37 & 0.38 & 1.03 & 0.40 & 1.08 & 3.32 & 3.61 & 1.09 & 3.60 & 1.08 \\
\hline LC & 0.34 & 0.41 & 1.21 & 0.49 & 1.44 & 3.62 & 3.34 & 0.92 & 2.94 & 0.81 \\
\hline LW & 0.38 & 0.40 & 1.05 & 0.42 & 1.11 & 3.24 & 3.43 & 1.06 & 3.43 & 1.06 \\
\hline $\mathrm{RW}$ & 0.35 & 0.33 & 0.94 & 0.36 & 1.03 & 3.51 & 4.15 & 1.18 & 4.00 & 1.14 \\
\hline MH & 0.35 & 0.42 & 1.20 & 0.47 & 1.34 & 3.51 & 3.26 & 0.93 & 3.06 & 0.87 \\
\hline MG & 0.34 & 0.38 & 1.12 & 0.37 & 1.09 & 3.62 & 3.61 & 1.00 & 3.89 & 1.08 \\
\hline AVG & 0.35 & 0.39 & 1.12 & 0.42 & 1.20 & 3.56 & 3.57 & 1.01 & 3.50 & 0.99 \\
\hline STD & 0.02 & 0.03 & 0.11 & 0.04 & 0.15 & 0.26 & 0.27 & 0.10 & 0.37 & 0.12 \\
\hline
\end{tabular}


Table 36. Measured and Calculated Gamma-Ray Dose Rates and Reduction Factors.

Free-Field, Phantom Facing the Reactor.

Comparisons with ETCA Measurements.

Dose rates in $\mathrm{mrad}_{\mathrm{T}} / \mathrm{kWh}$.

\begin{tabular}{ccccccccccc}
\hline \multicolumn{10}{c}{} & \multicolumn{10}{c}{ Run Number 130/131 } \\
\hline & DOSE & OR & C/M & SAI & C/M & RF & OR & C/M & SAI & C/M \\
\hline OUT & 1.39 & 1.35 & 0.99 & 1.32 & 0.95 \\
BOX & 0.32 & 0.40 & 1.25 & 0.41 & 1.28 & 4.34 & 3.38 & 0.78 & 3.42 & 0.79 \\
\hline & & & \multicolumn{10}{c}{ Free-Field Dose } \\
\hline FB & 1.82 & 1.81 & 0.99 & 1.89 & 1.04 & 0.76 & 0.75 & 0.99 & 0.70 & 0.92 \\
BB & 1.43 & 1.43 & 1.00 & 1.53 & 1.07 & 0.97 & 0.94 & 0.97 & 0.86 & 0.89 \\
LC & 1.77 & 1.78 & 1.01 & 1.76 & 0.99 & 0.79 & 0.76 & 0.96 & 0.75 & 0.95 \\
LW & 1.52 & 1.47 & 0.97 & 1.53 & 1.01 & 0.91 & 0.92 & 1.01 & 0.86 & 0.95 \\
RW & 1.50 & 1.57 & 1.05 & 1.55 & 1.03 & 0.93 & 0.86 & 0.92 & 0.85 & 0.91 \\
MH & 1.86 & 1.96 & 1.05 & 1.96 & 1.05 & 0.75 & 0.69 & 0.92 & 0.68 & 0.91 \\
MG & 1.81 & 1.95 & 1.08 & 1.96 & 1.08 & 0.77 & 0.69 & 0.90 & 0.67 & 0.87 \\
\hline \hline AVG & 1.67 & 1.71 & 1.02 & 1.74 & 1.04 & 0.84 & 0.80 & 0.95 & 0.77 & 0.91 \\
STD & 0.17 & 0.20 & 0.04 & 0.19 & 0.03 & 0.09 & 0.10 & 0.04 & 0.08 & 0.03 \\
\hline \hline
\end{tabular}


Table 37. Measured and Calculated Gamma-Ray Dose Rates and Reduction Factors.

In-Box, Phantom Facing the Reactor.

Comparisons with ETCA Measurements.

Dose rates in $\operatorname{mrad}_{T} / \mathrm{kWh}$.

\begin{tabular}{|c|c|c|c|c|c|c|c|c|c|c|}
\hline \multicolumn{11}{|c|}{ Run Number 123} \\
\hline & DOSE & OR & $\mathrm{C} / \mathrm{M}$ & SAI & $\mathrm{C} / \mathrm{M}$ & $\mathrm{RF}$ & OR & $\mathrm{C} / \mathrm{M}$ & SAI & $\mathrm{C} / \mathrm{M}$ \\
\hline \multicolumn{11}{|c|}{ Free-Field Dose } \\
\hline OUT & 1.38 & 1.35 & 0.98 & 1.28 & 0.93 & & & & & \\
\hline BOX & 0.38 & 0.38 & 1.00 & 0.38 & 1.00 & 3.63 & 3.55 & 0.98 & 3.37 & 0.93 \\
\hline \multicolumn{11}{|c|}{ Dose in Phantom } \\
\hline FB & & 0.40 & & 0.40 & & & 3.38 & & & \\
\hline BB & 0.35 & 0.34 & 0.97 & 0.35 & 1.00 & 3.94 & 3.97 & 1.01 & 3.66 & 0.93 \\
\hline LC & 0.40 & 0.40 & 1.00 & 0.41 & 1.03 & 3.45 & 3.38 & 0.98 & 3.12 & 0.90 \\
\hline LW & 0.38 & 0.37 & 0.97 & 0.37 & 0.97 & 3.63 & 3.65 & 1.01 & 3.46 & 0.95 \\
\hline RW & 0.34 & 0.37 & 1.09 & 0.39 & 1.15 & 4.06 & 3.65 & 0.90 & 3.28 & 0.81 \\
\hline MH & 0.44 & 0.39 & 0.89 & 0.40 & 0.91 & 3.14 & 3.46 & 1.10 & 3.20 & 1.02 \\
\hline MG & 0.34 & 0.35 & 1.03 & 0.36 & 1.06 & 4.06 & 3.86 & 0.95 & 3.56 & 0.88 \\
\hline AVG & 0.37 & 0.37 & 0.99 & 0.38 & 1.02 & 3.71 & 3.62 & 0.99 & 3.38 & 0.91 \\
\hline STD & 0.03 & 0.02 & 0.06 & 0.02 & 0.07 & 0.34 & 0.21 & 0.06 & 0.19 & 0.07 \\
\hline
\end{tabular}


Table 38. Measured and Calculated Gamma-Ray Dose Rates and Reduction Factors.

In-Box, Phantom Left Side Facing the Reactor.

Comparisons with ETCA Measurements.

Dose rates in $\operatorname{mrad}_{T} / \mathrm{kWh}$.

\begin{tabular}{ccccccccccc}
\hline \multicolumn{10}{c}{ Run Number 121/122 } \\
\hline & DOSE & OR & C/M & SAI & C/M & RF & OR & C/M & SAI & C/M \\
\hline OUT & 1.30 & 1.35 & 1.04 & 1.30 & 1.00 \\
BOX & 0.36 & 0.38 & 1.06 & 0.38 & 1.06 & 3.61 & 3.55 & 0.98 & 3.42 & 0.95 \\
\hline & & \multicolumn{7}{c}{ Dose in Phantom } \\
\hline FB & & 0.37 & & 0.37 & & & \\
BB & 0.32 & 0.37 & 1.16 & 0.37 & 1.16 & 4.06 & 3.65 & 0.90 & 3.51 & 0.87 \\
LC & 0.35 & 0.39 & 1.11 & 0.46 & 1.31 & 3.71 & 3.46 & 0.93 & 2.83 & 0.76 \\
LW & 0.36 & 0.39 & 1.08 & 0.40 & 1.11 & 3.61 & 3.46 & 0.96 & 3.25 & 0.90 \\
RW & 0.37 & 0.32 & 0.86 & 0.32 & 0.86 & 3.51 & 4.22 & 1.20 & 4.06 & 1.16 \\
MH & 0.41 & 0.39 & 0.95 & 0.43 & 1.05 & 3.17 & 3.46 & 1.09 & 3.02 & 0.95 \\
MG & 0.36 & 0.33 & 0.92 & 0.31 & 0.86 & 3.61 & 4.09 & 1.13 & 4.19 & 1.16 \\
\hline \hline AVG & 0.36 & 0.37 & 1.01 & 0.38 & 1.06 & 3.61 & 3.71 & 1.04 & 3.48 & 0.97 \\
STD & 0.03 & 0.03 & 0.11 & 0.05 & 0.16 & 0.26 & 0.29 & 0.11 & 0.51 & 0.15 \\
\hline \hline
\end{tabular}




\section{REFERENCES}

1. J. O. Johnson, "A User's Manual for MASH 1.0: A Monte Carlo Adjoint Shielding Code System", Oak Ridge National Laboratory, ORNL/TM-11778, (March 1992).

2. W. A. Rhoades and M. B. Emmett,"Vehicle Code System (VCS) User's Manual", Oak Ridge National Laboratory, ORNL/TM-4648, (August 1974).

3. W. A. Rhoades, et. al., "Development of a Code System for Determining Radiation Protection for Armored Vehicles (The VCS Code)", Oak Ridge National Laboratory, ORNL/TM-4664, (October 1964).

4. J. O. Johnson, J. D. Drischler, and J. M. Barnes, "Analysis of the Fall-1989 Two-Meter Box Test Bed Experiments Performed at the Army Pulse Radiation Facility (APRF)", Oak Ridge National Laboratory, ORNL/TM-11777 (May 1991).

5. Dean C. Kaul and Stephen D. Egbert, "Radiation Environments Program (REP) The Verification \& Validation of MASH 1991, 1990, 1989", presented at the REP Program Meeting, WWD, Munster, Germany, 28-29 July 1992, (Unpublished).

6. R. T. Santoro, et. el., "DNA Radiation Environments Program Fall 1989 2-Meter Box Experiments and Analysis", Oak Ridge National Laboratory, ORNL/TM-11840, (May 1991).

7. R. T. Santoro and S. Y. Whitaker, "DNA Radiation Environments Program Spring 1990 2-m Box Experiments and Analysis", Oak Ridge National Laboratory, ORNL/TM-12160, (September 1992).

8. J. O. Johnson, J. D. Drischler, and J. M. Barnes, "Analysis of the Spring 1990 TwoMeter Box Test Bed Experiments Performed at the Army Pulse Radiation Facility (APRF)", Oak Ridge National Laboratory, ORNL/TM-11917,(August 1992).

9. J. O. Johnson, J. D. Drischler, and J. M. Barnes, "Analysis of the Spring 1991 TwoMeter Box Test Bed Experiments Performed at the Army Pulse Radiation Facility (APRF)", Oak Ridge National Laboratory, ORNL/TM-11918, (September 1992).

10. K. Tremblay, H. Ing, and R. A. Noulty, "Anthropomorphic Phantom Radiation Dosimetry Measurements", Bubble Technology Industries, Inc., BTI-90/6-6, (1992).

11. Mark A. Oliver, "Army Pulse Radiation Facility (APRF) Gamma Dose Measurements: 400-m Phantom", U.S. Army Combat Systems Test Activity, DNA-TR-92-27, (February 1993).

12. APRF Unpublished Report on Bubble Detector Results, (1991). 
13. E. Kearsley, Memorandum for RARP, Armed Forces Radiobiology Research Institute, (1991), Unpublished.

14. Klaus G. Kerris, "HDL Gamma Dose Measurements at the 400-m Position using $\mathrm{CaF}_{2}: \mathrm{Mn}$ Thermoluminescent Detectors", Harry Diamond Laboratories, (1991), Unpublished.

15. Joe̊l Dehrmain, Unpublished Results of Spring 1991 APRF Neutron and Gamma-Ray Measurements, Notes to J. O. Johnson, ORNL (1991), Unpublished.

16. D. T. Ingersoll, R. W. Roussin, C. Y. Fu, and J. E. White, "DABL69: A Broad Group Neutron/Photon Cross-Section Library for Defense Nuclear Application", Oak Ridge National Laboratory, ORNL/TM-10568, (June 1989).

17. R. T. Santoro, J. D. Drischler, and J.O. Johnson, "Resolution of Dose and Reduction Factor Questions in Army Pulse Radiation Facility Experiments: Renormalization of Calculated and Measured Data", Oak Ridge National Laboratory, ORNL/TM-12148, (November 1992). 


\section{APPENDIX A}

\section{SPRING 1991 2-METER BOX EXPERIMENTS \\ List of Participants by Organization}

\section{EXPERIMENTALISTS}

Army Pulse Radiation Facility

Aberdeen Proving Ground, Maryland, USA 21005-5059

C. H. Heimbach, M. A. Oliver, A. H. Kazi

Armed Forces Radiobiology Research Institute

Bethesda, Maryland, 20889

E. Kearsley

Establissement Technique Central de l'Armement

Centre'd Etudes du Bouchet

94114 Arcueil, France

J. Dhermain, G. Nurdin, J. Laugier

Harry Diamond Laboratory

2300 Powder Mill Road

Adelphi, Maryland, USA

K. Kerris

\section{ANALYSTS}

Oak Ridge National Laboratory

P.O. Box 2008

Oak Ridge, Tennessee, USA 37831

J. M. Barnes, J. D. Drischler, J. O. Johnson

Science Applications International Corporation

San Diego, California USA 92121

S. D. Egbert, D. C. Kaul 


\section{INTERNAL DISTRIBUTION}

1. B. R. Appleton

2-6. J. M. Barnes

7. T. J. Burns

8-12. J. D. Drischler

13. C. M. Haaland

14. D. T. Ingersoll

15-19. J. O. Johnson

20. J. V. Pace

21. W. A. Rhoades

22. R. W. Roussin

23. R. T. Santoro

24. J. O. Stiegler
25. R. C. Ward

26-27. EPMD Reports Office

28-29. Laboratory Records

Department

30. Laboratory Records ORNL-RC

31. Document Reference Section

32. Central Research Library

33. ORNL Patent Section

\section{EXTERNAL DISTRIBUTION}

33. Director, Defense Nuclear Agency

ATTN: RARP (Dr. D. L. Auton)

6801 Telegraph Road

Alexandria, VA 22310-3398

34. Dr. Roger W. Brockett

Wang Professor of Electrical Engineering

and Computer Science

Division of Applied Science

Harvard University

Cambridge, Massachusetts 02138

35. Dr. N. Ricky Byrn

Nicholes Research Corp.

4040 So. Memorial Parkway

Huntsville, AL 35802

36. Director, Army Research Laboratory

ATTN: AMSRL-WT-NH (Mr. John Corrigan)

2800 Powder Mill Road

Adelphi, MD 20783-1197 
37. Electronics Division, NES

ATTN: Dr. Tom Cousins

Defence Research Establishment Ottawa

Ottawa, Ontario, Canada, K1A OZ4

38. Commander, U.S. Army Nuclear \& Chemical Agency

ATTN: MONA-ZB (Dr. David Bash)

7500 Backlick Rd., Bldg. 2073

Springfield, VA 22150-3198

39. Establissment Technique Central de l'Armement

ATTN: Dr. Joel Dhermain

Centre d'Etudes du Boucher

16 bis Avenue Prieur de la Cote d'or

94114 Arcueil-Cedex, France

40. Prof. Donald J. Dudziak

110B Burlington Engineering Labs

North Carolina State University

Raleigh, NC 27695-7:09

41. Science Applications International Corporation

ATTN: Dr. Stephen Egbert

10260 Campus Point Drive

San Diego, CA 92121

42. Commander, U.S. Army Combat Systems Test Activity

ATTN: STECS-NE (Mr. John Gerdes)

Aberdeen Proving Ground, MD 21005-5059

43. Ministry of Defence, Atomic Weapons Establishment

ATTN: Dr. Kevin G. Harrison

Building A72, Aldermaston,

Reading, Berkshire, United Kingdom, RG7 4PR

44. Commander, U.S. Army Combat Systems Test Activity

ATTN: STECS-NE (Dr. C. Heimbach)

Aberdeen Proving Ground, MD 21005-5059

45. Director, Bubble Technology Industries, Inc.

ATTN: Dr. Harry Ing

Highway 17

Chalk River, Ontario, Canada, KOJ 1JO

46. Science Applications International Corporation

ATTN: Mr. Dean C. Kaul

10260 Campus Point Drive

San Diego, CA 92121 
47. Commander, U.S. Army Combat Systems Test Activity ATTN: STECS-NE (Dr. A. Halim Kazi)

Aberdeen Proving Ground, MD 21005-5059

48. Director, Armed Forces Radiobiology Research Institute ATTN: MRAD (CDR Kearsly)

Bethesda, MD 20814-5145

49. Director, Defense Nuclear Agency

ATTN: RARP (MAJ Robert Kehlet)

6801 Telegraph Road

Alexandria, VA 22310-3398

50. Director, Army Research Laboratory

ATTN: AMSRL-WT-NH(Mr. Klaus Kerris)

2800 Powder Mill Road

Adelphi, MD 20783-1197

51. US Army Center for EQ/RSTA

ATTN: AMSEL-RSK (Dr. Stanley Kronenberg)

Fort Monmouth, NY 07703

52. Establissment Technique Central de l' Armement

ATTN: Dr. Jacques Laugier

Centre d'Etudes du Boucher

16 bis Avenue Prieur de la Cote d'or

94114 Arcueil-Cedex, France

53. Dr. James E. Leiss

Route 2, Box 142C

Broadway, VA 22815

54. Dr. Neville Moray

Department of Mechanical and Industrial Engineering

University of Illinois

1206 West Green Street

Urbana, Il 61801

55. Director, Defense Nuclear Agency

ATTN: RARP (Ms. Joan Ma Pierre)

6801 Telegraph Road

Alexandria, VA 22310-3398

56. Naval Surface Warfare Center

ATTN: CODE R41 (Mr. Gordon Reil)

New Hampshire Road

White Oak, MD 20903-5000 
57. Commander, U.S. Army Foreign Science \& Technology Center ATTN: UVA (Dr. Roger Rydin)

2207 th Street NE

Charlottesville, VA 22901-5396

58. HEAD, Nuclear Radiation Effects

ATTN: Dr. Ludwig Schaenzler

Wehrwissenschaftliche Dienststelle

Postfach 1320

3042 Munster

Federal Republic of Germany

59. David L. Tilson

U.S. Army SDC

ATTN: CSSD-SA-EV

P.O. BOx 1500

Huntsville, AL 35807

60. Commander, U.S. Army Foreign Science \& Technology Center ATTN: AIFRTA (Mr. Charles Ward)

2207 th Street NE

Charlottesville, VA 22901-5396

61. Dr. Mary F. Wheeler

Department of Mathematical Sciences

Rice University

P. O. Box 1892

Houston, Tx 77204-3476

62-64. S. Y. Whitaker 1830 Delphine Drive

Decatur, GA 30032

65. Commander, U.S. Army Tank Automotive Command ATTN: AMSTA-RSK (Mr. Greg Wolfe)

Bldg. 200

Warren, MI 48317-5000

66. Director, Defense Nuclear Agency

ATTN: RARP (Dr. Robert Young)

6801 Telegraph Road

Alexandria, VA 22310-3398

67. Office of the Assistant Manager for Energy

Research and Development

Department of Energy, Oak Ridge Operations

P.O. Box 2001

Oak Ridge, TN 37831 
68-69. Office of Scientific and Technical Information P.O. Box 62

Oak Ridge, TN 37830 

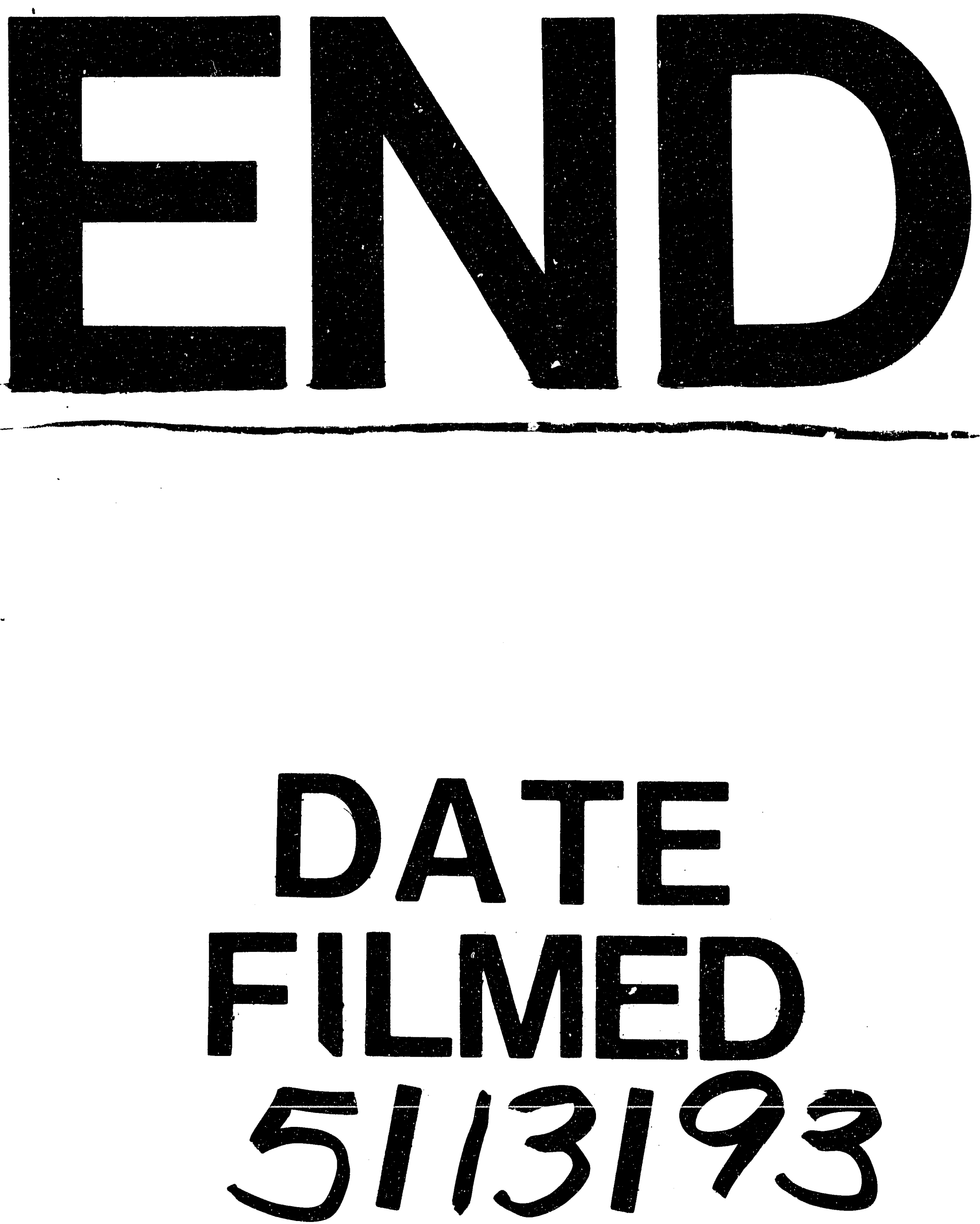
